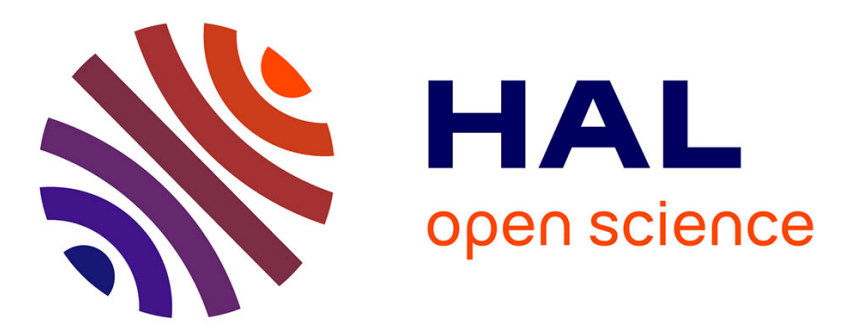

\title{
COMPARATIVE PHYLOGEOGRAPHY OF TWO AGAROPHYTON SPECIES IN THE NEW ZEALAND ARCHIPELAGO
}

\author{
Oscar R Huanel, Wendy A Nelson, Vanessa Robitzch, Stéphane Mauger, \\ Sylvain Faugeron, Maren Preuss, Giuseppe Zuccarello, Marie-Laure Guillemin
}

\section{- To cite this version:}

Oscar R Huanel, Wendy A Nelson, Vanessa Robitzch, Stéphane Mauger, Sylvain Faugeron, et al.. COMPARATIVE PHYLOGEOGRAPHY OF TWO AGAROPHYTON SPECIES IN THE NEW ZEALAND ARCHIPELAGO. Journal of Phycology, In press, 10.1111/jpy.13046 . hal-03002124

\section{HAL Id: hal-03002124 \\ https: / hal.sorbonne-universite.fr/hal-03002124}

Submitted on 12 Nov 2020

HAL is a multi-disciplinary open access archive for the deposit and dissemination of scientific research documents, whether they are published or not. The documents may come from teaching and research institutions in France or abroad, or from public or private research centers.
L'archive ouverte pluridisciplinaire HAL, est destinée au dépôt et à la diffusion de documents scientifiques de niveau recherche, publiés ou non, émanant des établissements d'enseignement et de recherche français ou étrangers, des laboratoires publics ou privés. 
Oscar R. Huanel

Departamento de Ecología, Facultad de Ciencias Biológicas, Pontificia Universidad Católica de Chile, Casilla 114-D, Santiago, Chile.

CNRS, Sorbonne Université, UMI 3614, Evolutionary Biology and Ecology of Algae, Station Biologique de Roscoff, CS 90074, Place G. Tessier, 296888, Roscoff, France.

Wendy A. Nelson

National Institute of Water and Atmospheric Research, Wellington 6021, New Zealand. School of Biological Sciences, University of Auckland, Auckland 1142, New Zealand.

Vanessa Robitzch

Instituto de Ciencias Ambientales y Evolutivas, Facultad de Ciencias, Universidad Austral de Chile, Casilla 567, Valdivia, Chile.

Stéphane Mauger

CNRS, Sorbonne Université, UMI 3614, Evolutionary Biology and Ecology of Algae, Station Biologique de Roscoff, CS 90074, Place G. Tessier, 296888, Roscoff, France.

Sylvain Faugeron 
Departamento de Ecología, Facultad de Ciencias Biológicas, Pontificia Universidad Católica de Chile, Casilla 114-D, Santiago, Chile.

CNRS, Sorbonne Université, UMI 3614, Evolutionary Biology and Ecology of Algae, Station Biologique de Roscoff, CS 90074, Place G. Tessier, 296888, Roscoff, France.

Maren Preuss

School of Biological Sciences, Victoria University of Wellington, Wellington 6140, New Zealand.

Giuseppe C. Zuccarello

School of Biological Sciences, Victoria University of Wellington, Wellington 6140, New Zealand.

Marie-Laure Guillemin ${ }^{2}$

CNRS, Sorbonne Université, UMI 3614, Evolutionary Biology and Ecology of Algae, Station Biologique de Roscoff, CS 90074, Place G. Tessier, 296888, Roscoff, France. Instituto de Ciencias Ambientales y Evolutivas, Facultad de Ciencias, Universidad Austral de Chile, Casilla 567, Valdivia, Chile.

${ }^{2}$ Corresponding author: marielaure.guillemin@gmail.com; +56 968496214

Running title: Phylogeography of NZ Agarophyton 
Abstract

Molecular studies have reported the co-existence of two species of Agarophyton in New Zealand: the newly described $A$. transtasmanicum with an apparently restricted distribution to some sites in the North Island, and the more wide-spread $A$. chilense. Here we compared the distribution, genetic diversity, and structure of both Agarophyton species throughout the archipelago using sequences of the nuclear Internal Transcribed Spacer 2 (ITS2) marker. Agarophyton chilense's distribution was continuous and extensive along the North and South Islands, Stewart Island, and Chatham Island, and the genetic clusters were mostly concordant with boundaries between biogeographic regions. In contrast, specimens of $A$. transtasmanicum were collected in four sites broadly distributed in both the North and South Islands, with no clear spatial structure of the genetic diversity. Populations where the species co-occurred, tended to display similar levels in genetic diversity for the two species. Demographic inferences supported a post-glacial demographic expansion for two $A$. chilense genetic clusters, one present in the South Island and the eastern coast of the North Island, and the other present in northern South Island. A third genetic cluster located on the western coast of the North Island had a signature of long-term demographic stability. For $A$. transtasmanicum, the skyline plot also suggested a post-glacial demographic expansion.

Last, we developed a new molecular tool to quickly and easily distinguish between the two Agarophyton species, which could be used to ease future fine-scale population studies, especially in areas where the two species co-exist.

Keywords: biogeographic and oceanographic barriers, demography, glacial-interglacial 
cycles, Gracilariales, ITS2, parapatric genetic clusters, species co-occurrence, species diagnostic molecular tool.

Abbreviations: ITS2, Internal Transcribed Spacer 2; SSD, Sum squared deviations; BSP, Bayesian skyline plots; LGM, Last Glacial Maximum; AMOVA, Analysis of Molecular Variance; SAMOVA, Spatial Analysis of Molecular Variance; MCMC, Markov Chain Monte Carlo.

\section{INTRODUCTION}

A large proportion of marine algae in New Zealand are endemic (e.g., up to $40 \%$ of Rhodophyceae, Nelson 2012), which is considered to be a consequence of in situ radiations of ancient Gondwanan lineages after the separation of Zealandia from Australasia, and from taxa that colonized New Zealand after the Oligocene marine transgression, during which most of the archipelago was submerged (McDowall 2008, Neall and Trewick 2008, Sharma and Wheeler 2013, Wallis and Jorge 2018, McCulloch and Waters 2019). However, a

| number of marine species present in New Zealand also inhabit other regions of the southern hemisphere, such as Australia, sub-Antarctic islands, and South America (Waters 2008, Fraser et al. 2009b, Fraser et al. 2013, Guillemin et al. 2014). Phylogeographic studies have suggested that many of these disjoint distributions have been the result of west to east transoceanic dispersal at the end of the Pleistocene (Waters and Roy 2004, Waters et al. 2006, Waters 2008, Fraser et al. 2009b, Fraser et al. 2013, Guillemin et al. 2014). 
The genus Agarophyton (Gracilariales) is one example of an algal taxon present across the South Pacific: A. chilense is distributed in New Zealand including Chatham Island, and South America, while A. transtasmanicum is present in mainland Australia, Tasmania, and New Zealand (Candia et al. 1999, Cohen et al. 2004, Guillemin et al. 2014, Preuss et al. 2020). The order Gracilariales is well represented in New Zealand, including eleven species from the genera Agarophyton, Crassiphycus, Curdiea, and Melanthalia

| (Gurgel et al. 2018, Neill \& Nelson 2019, Preuss et al. 2020). Members of the Gracilariales possess an isomorphic haploid-diploid life cycle (Gurgel et al. 2018) and reproduction is either sexual or asexual (Santelices and Doty 1989). During sexual reproduction, spores (both haploid and diploid) develop into morphologically identical thalli attached by holdfasts to hard substrates (Kain and Destombe 1995). Asexual reproduction results from the survival and growth of thallus fragments separated from their holdfast. Such clonal propagation allows the species to form dense mats embedded in soft substrate, in protected bays or estuaries. The capacity to switch between sexual and asexual reproduction has contributed to the success of the invasive A. vermiculophyllum (Krueger-Hadfield et al. 2016) and to the extensive cultivation of A. chilense, in Chile (Santelices and Doty 1989, Buschmann et al. 2001). Their unattached thalli generally correspond to diploid tetrasporophytes growing vegetatively (Guillemin et al. 2008, Krueger-Hadfield et al. 2016). Various ecological traits further explain the success of these species, including a fast growth rate, low palatability in non-native habitats, and tolerance to a wide range of light | and salinity conditions (Hammann et al. 2013, Hu and Lopez-Bautista 2014, Kim et al. 2016). 
Two terete species of Agarophyton coexist in New Zealand: A. chilense and A. transtasmanicum. Agarophyton chilense grows in estuarine environments and along the open coast in sites characterized by moderate wave exposure (Nelson 1987, Nelson et al. 2015). Populations are usually found attached to cobbles, shells and sometimes on rocky substrates, but large agglutinations of entangled thalli have also been occasionally reported on soft substrates (e.g., mud or sand; Nelson 1987, Nelson et al. 2015). Agarophyton transtasmanicum shares the same habitat. Its floating thalli can be found in sandy/muddy substrates of highly protected bays, and only a few individuals are found growing on cobbles and rocks as the result of spore settlement (Wilcox et al. 2001, 2007, Nelson et al. 2015). In the absence of external diagnostic characters (Preuss et al. 2020), $A$. transtasmanicum was first identified from phylogenetic studies as a sibling lineage of $A$. tenuistipitatum, and genetically divergent from A. chilense (Candia et al. 1999, Cohen et al. 2004). Agarophyton transtasmanicum was reported among samples from Blockhouse Bay in New Zealand (near Auckland; Candia et al. 1999), mainland Australia and Tasmania (Byrne et al. 2002, Cohen et al. 2004, Preuss et al. 2020). The main phenotypic difference between $A$. transtasmanicum and A. chilense is related to the number of medullary layers and cortex-to-medulla transition (Preuss et al. 2020). A further difference between the two species was also demonstrated by the presence of gigartinine in the former species but not in the latter (Wilcox et al. 2001, 2007). Samples of A. transtasmanicum attached to rocky substrate were also observed in the southern west coast of North Island (e.g., the Whanganui and Manawatu River mouths), leading to the idea that the species' distribution range in New Zealand may still be underestimated (Preuss et al. 2020). 
Gigartinine is an amino acid likely acting as a nitrogen reserve allowing sustained growth between nitrogen pulses (Laycock and Craigie 1977). Wilcox et al. (2007) proposed that the quick accumulation of nitrogen in form of gigartinine (in a few hours) by $A$. transtasmanicum could confer an ecological advantage over $A$. chilense in terms of nitrogen storage and ultimately of growth rate. Because the two species seem to occupy the same habitat, such an ecological advantage could lead to the replacement of $A$. chilense by A. transtasmanicum. The existence of such an ecological advantage is not supported by current field reports, since most of the known distribution Agarophyton along New Zealand's coasts is currently attributed to A. chilense. However, the lack of external features to distinguish the two species has likely biased these records (Preuss et al. 2020) and the actual distribution range of both species remains to be determined. Thus, the aims of this study were 1) to investigate the range of the distribution of $A$. chilense and $A$.

I transtasmanicum in the New Zealand archipelago based on genetic identification; 2) to compare patterns of genetic diversity, structure, and past demographic inferences of $A$. chilense and A. transtasmanicum to study co-existence of the two species from an evolutionary perspective; and 3) to develop an identification toolkit based on based on species-specific genetic markers to easily distinguish between these two species in future studies.

\section{MATERIALS AND METHODS}

Sampling 
Because morphological distinction between the two species was not possible in the field, we performed a random sampling in two types of habitats: pebbles, seashells, or rocky substrate on which thalli could settle and attach to, versus soft substrates on which only floating vegetative fragments were present. A total of 559 individuals of Agarophyton were collected from 25 sites throughout New Zealand, including the North and South Islands, Stewart Island, and Chatham Island (Table 1).

Collections were made under a special permit $\left(\mathrm{N}^{\circ} 666\right)$ to NIWA from the New Zealand Ministry of Primary Industries. All samples were stored in plastic bags with silica gel to preserve the tissue before DNA extraction. Voucher specimens were deposited in the herbarium of the Museum of New Zealand Te Papa Tongarewa (WELT - Thiers 2019).

\section{DNA extraction, PCR amplification, sequencing, and alignment}

Genomic DNA was isolated from pulverized dry tissue using the Chelex method following Cohen et al. (2004). The Internal Transcribed Spacer 2 (ITS2) was amplified using the primers CD12F (5'-TACAAATTGGACTTTGGCATTCTGGG-3'; Wattier et al. 1997) and AB28 (5'-GGGATCCATATGCTTAAGTTCAGCGGGT-3'; Goff and Moon 1993). Amplification reactions ( $30 \mu \mathrm{L}$ ) contained $1 \mathrm{x}$ reaction buffer, $2.5 \mathrm{mM} \mathrm{MgCl}_{2}, 0.2$ $\mathrm{mM}$ dNTPs, $0.3 \mu \mathrm{M}$ of each primer, $1 \mathrm{U}$ Taq DNA polymerase (Thermo Fisher Scientific, Inc.), and $3 \mu \mathrm{L}$ (ca. $50 \mathrm{nM}$ ) of template DNA. The PCR cycles were performed as described

| by Cohen et al. (2004). PCR products were purified using the UltraClean ${ }^{\mathrm{TM}}$ DNA Purification kit (MO BIO Laboratories, Carlsbad, CA, USA) and sequenced, using both PCR primers, with an ABI Automatic Sequencer at the AUSTRAL-OMICS core-facility 
(Universidad Austral de Chile, Chile). Sequences were edited using Chromas v.2.33

(McCarthy 1997) and the sequences' alignments were made with AliView (Larsson 2014).

Sequences of low frequency ribotypes were independently read twice, and any difficulty identifying variable sites led to sample re-sequencing. Within each species, indels were manually recoded as substitutions, considering one mutational event for each indel or group of consecutive indels.

Ninety-three sequences of $A$. chilense published by Guillemin et al. (2014) were added to our ITS2 data set. In total, 652 ITS2 sequences obtained from 27 sites were available for phylogeographic analyses (Table 1). Twenty of these sites were on hard substrates with settled individuals, while seven sites were soft substrates colonized by floating thalli (Table 1). Species assignment was achieved by comparing ITS2 sequences obtained in this study with the ones already published in Cohen et al. (2004).

\section{Phylogeographic structure and population genetic diversity}

| For each species, genealogical relationships between ITS2 ribotypes were reconstructed using Median-Joining implemented in NETWORK v5.0.1.1 (Bandelt et al. 1999). Population genetic structure was examined by calculating pairwise $\Phi_{\mathrm{ST}}$ between populations within each species; and significance of the $\Phi_{\mathrm{ST}}$ values was estimated using 1,000 permutations (Excoffier et al. 1992). For each Agarophyton species independently, Analysis of Molecular Variance (AMOVA) was used to test for the partition of genetic variance among sites and among bioregions. The bioregions were defined using the Coastal Biogeographic Regions' Classification map provided by the Ministry for the Environment 
of New Zealand (http://www.mfe.govt.nz/more/science-and-data/classification-systems/

marine-classification-systems). Additionally, the existence of differentiated genetic clusters in A. chilense was evaluated by Spatial Analysis of Molecular Variance implemented in SAMOVA 2.0 (Dupanloup et al. 2002). This analysis allows the identification of groups of spatially contiguous populations by maximizing the among-group component $\left(\mathrm{F}_{\mathrm{CT}}\right)$ of the overall genetic variance. SAMOVA was performed using 1,000 simulated annealing procedures for $K$-values ranging from 2 to 10 groups. Configurations containing groups with a single population were not considered. An AMOVA was then used to estimate the I partition of genetic variance among sites and among genetic clusters. Tests for isolation by distance within species were performed using Mantel tests. All analyses were performed in ARLEQUIN v3.5 (Excoffier and Lischer 2010).

The genetic diversity of $A$. chilense and $A$. transtasmanicum was evaluated using five indices, calculated within each sampling site, within each genetic cluster, and within each species. The number of ribotypes (nR), gene diversity $(H)$, nucleotide diversity $(\pi)$, number of private ribotypes (Rpriv), and number of polymorphic sites (S) were calculated in DNASP 4.10.3 (Rozas et al. 2003). The number of ribotypes corrected for differential sample size (nRrar) was estimated using the rarefaction method developed in CONTRIB 1.02 (Petit et al. 1998). A rarefaction size of eight was used for estimating nRrar at each site in both species. The rarefaction size corresponds to the lowest number of sequences available in any sampled locality: GOLD in A. chilense and OHOP in A. transtasmanicum (Table 1). In A. transtasmanicum, the locality HINA was excluded from the rarefaction analysis due to its small sample size $(\mathrm{N}=3$, Table 1). Mann-Whitney U-tests were 
performed to test for significant differences of genetic diversity (indices nRrar, $\mathrm{H}$, and $\pi$ were used) between the Agarophyton species in R Studio v1.2.1335 (R Core Team, 2019).

\section{Demographic history}

Tajima's D (Tajima 1989) and Fu's F (Fu 1997) tests were used to assess significant excess of rare alleles, performing 10,000 bootstrap replicates in ARLEQUIN v3.5

(Excoffier and Lischer 2010). Observed mismatch distributions, the distribution of the numbers of pairwise differences among all ribotypes, were fitted to a model of demographic growth coupled with spatial expansion (Ray et al. 2003) and its statistical significance was tested with the sum of squared deviations (SSD) statistic after 10,000 bootstraps. Bayesian skyline plots (BSP) were constructed using BEAST v2.5.1

(Drummond et al. 2012). The optimal nucleotide substitution model for ITS2 was estimated using MODELGENERATOR (Keane et al. 2006). Based on the Bayesian Information Criterion (BIC), the substitution models selected were F81 for A. chilense and F81 + I + G

for A. transtasmanicum. Bayesian skyline plots were constructed with 50 million iterations. Posterior distributions of parameters were approximated by Markov Chain Monte Carlo (MCMC) sampling, with samples drawn every 10,000 iterations after a discarded burn in of the first 5 million iterations. A log-normal, relaxed molecular clock was used, with a mutation rate 10 times higher (Ho et al. 2011) than the substitution rate of $0.71 \%-0.83 \%$ per million years estimated for ITS1 (Zuccarello and West 2002) to test for historical changes of effective population size. 
Development of a molecular tool to identify cryptic Agarophyton species in New Zealand A partial sequence of the mitochondrial cytochrome c oxidase subunit I gene (5PCOI) was obtained for a subset of $A$. chilense and A. transtasmanicum specimens. Seventeen specimens of $A$. chilense from New Zealand (sample sites: AHUR, BRIG, CASS, CHAT, HINA, MOMO, MOUT, OHOP, OKAR, PARE, OTAG, WAIN, STEW, WITI, SHEL, and RAGL; population abbreviations as in Table 1) and five specimens from Chile (sample sites: FCAL, FLEN, FTUB, NDIC, and NTUB; see Table 1 from Guillemin et al. 2008 for more information about sampling sites) were sequenced. For $A$. transtasmanicum, 10 specimens were sequenced: four from the North Eastern region (OHIW and OHOP), four from the North and South Cook Strait (WANG and MOIN), and two from the Southern South Island (CALA) (two specimens sequenced per site; population abbreviations and bioregions as in Table 1). The PCR conditions and primers (i.e., GaZF1 and GaZR1) described by Saunders (2005) were used for all individuals of both species.

Two consensus sequences, one for each species, were generated using GENEIOUS (http://www.geneious.com) to design new specific primers. First, a primer pair was designed in the highly conserved domain of the 5P-COI in order to amplify a positive control of the PCR in both species. These primers were Agarophyton_COI_F (5'CACCTACTTCTACAATTGCTGATG -3') and Agarophyton_COI_R (5'ATGGTAATGCCTGTWATGATTGG -3'). Second, two species-specific forward primers were designed in the 5P-COI region where a high number of fixed polymorphic sites discriminated between the two species: Agarophyton_chilense_COI_F (5'- 
CTAAAACAGGAACAGCTAATAGTAG -3') and Agarophyton_transtasmanicum_COI_F (5'-AACAGGGACAGCTAATAACAATAG -3'). The predicted sizes of the PCR products were 160 base pairs (bp) for Agarophyton_COI_F / Agarophyton_COI_R, 403 bp for Agarophyton_chilense_COI_F / Agarophyton_COI_R, and 399 bp for Agarophyton_transtasmanicum_COI_F/Agarophyton_COI_R.

In order to test the primers' ability to distinguish between the two Agarophyton species, two multiplex PCRs were performed for each sample. PCRs were carried out in a final volume of $10 \mu \mathrm{l}$ containing $1 \mathrm{X}$ buffer (Go Taq Flexi, Promega; Madison, USA), $0.5 \mu \mathrm{M}$ of each internal control primer (Agarophyton_COI_F and Agarophyton_COI_R), $0.5 \mu \mathrm{M}$ of one of the two species-specific primers (Agarophyton_chilense_COI_F or Agarophyton_transtasmanicum_COI_F), $1.5 \mathrm{mM} \mathrm{MgCl} 2,0.15 \mathrm{mM}$ dNTPs, 0.35

U Go Taq Flexi polymerase (Promega; Madison, USA), and $\sim 5$ ng of DNA template for each reaction. DNA amplifications were performed using an initial denaturation phase at $94^{\circ} \mathrm{C}$ for $5 \mathrm{~min}$, followed by 40 cycles with a $30 \mathrm{~s}$ denaturation at $95^{\circ} \mathrm{C}$, a 1 min annealing at $56^{\circ} \mathrm{C}$, and a $1 \mathrm{~min}$ extension at $72^{\circ} \mathrm{C}$, with a final extension at $72^{\circ} \mathrm{C}$ for $10 \mathrm{~min}$. Amplified fragments were visualized under UV light after electrophoresis on 2\% agarose gels stained with GelRed ${ }^{\mathrm{TM}}$ (Biotium, Fremont, USA).

\section{RESULTS}

A total of 652 ITS2 sequences, with an alignment length between 479 bp - 483 bp and 494 bp - 497 bp, were obtained for A. chilense and A. transtasmanicum, respectively. The alignment of the newly obtained sequences with those already published in Cohen et 
| al. (2004) confirmed the presence of the two species. In total, 556 samples were classified as A. chilense and 96 samples as A. transtasmanicum (Table 1). Among the Agarophyton collected in New Zealand, 72.5\% were collected attached to hard substrates (rocks, cobbles, shells) by a holdfast, while $27.5 \%$ were collected unattached, embedded in muddy substrate (Table 1).

Agarophyton chilense had a wide geographical distribution and was observed in all bioregions but was absent from three sampling sites, namely: Whanganui (WANG, attached thalli), in North Cook Strait, Ohiwa (OHIW, unattached thalli) in North Eastern, and Moutere Inlet (MOIN, unattached thalli) in South Cook Strait. The species was present attached to hard substrates in sites located nearby OHIW and MOIN, in Ohope (OHOP) and Moutere Inlet (MOUT), respectively (Table 1). The species was also encountered attached on rocky/shell substrates in 19 sites, and unattached, embedded in mud in five sites (Table 1). Agarophyton transtasmanicum was found in four regions, attached to hard substrates in three sites and unattached on soft substrate in another three sites. Attached individuals represented $78 \%$ of our sampling in A. chilense and $57 \%$ in A. transtasmanicum (Table 1). These proportions differed significantly from expected frequencies under random sampling in each substrate type (over the whole study, $72.5 \%$ of samples were expected to be attached to hard substrates given the number of samples and the number of sites with soft or hard substrate available; $\mathrm{X}^{2}=7.58$ for $A$. chilense; and $\mathrm{X}^{2}=44.35$ for $A$. transtasmanicum; critical value $\left.\mathrm{X}_{(0.05,1)}=3.84\right)$. The species co-occurred in three sites. In Ohope (OHOP) and Hinahina (HINA), individuals of both species were sampled attached to rocky/shell substrates, while in Catlins Lake (CALA) the individuals of both species 
were sampled unattached, forming dense mats in muddy substrates. In the South Cook Strait, A. chilense was found on hard substrate in Moutere Inlet (MOUT) while $A$.

transtasmanicum thalli were floating in MOIN, the two sites being only a few meters apart.

Intraspecific genetic diversity and structure

Among the 556 individuals of $A$. chilense sampled throughout New Zealand, 45

ITS2 ribotypes were detected (Fig. 1, see also Table S1). A total of 42 polymorphic sites were observed in the $483 \mathrm{bp}$ fragment, including four indels of $1 \mathrm{bp}$ or $2 \mathrm{bp}$ in length (Table 1; Fig. 1; GenBank accession numbers MN145944-MN145972, see Table S2). Ribotype r01 was the most frequent in New Zealand (60\%, 333 of the 556 A. chilense ITS2 sequences) and the only one shared with Chilean populations (Guillemin et al. 2014). Among the 96 individuals of $A$. transtasmanicum sampled, ten ITS2 ribotypes were detected (Fig. 2, see also Table S3). In the case of A. transtasmanicum, a total of four polymorphic sites were observed in the $496 \mathrm{bp}$ fragment, including two indels of $1 \mathrm{bp}$ (Table 1; Fig. 2; GenBank accession numbers MN145973-MN145982, see Table S2). At the species level, ribotype richness after rarefaction (nRrar), gene diversity $(\mathrm{H})$, and nucleotide diversity $(\pi)$ were all slightly higher in A. chilense than in A. transtasmanicum, but differences were not statistically significant ( $\mathrm{nRrar}=13.63$ and $\mathrm{nRrar}=9.00, \mathrm{U}=34, p=$ $0.771 ; \mathrm{H}=0.614 \pm 0.022$ and $\mathrm{H}=0.504 \pm 0.058, \mathrm{U}=33, p=0.480 ; \pi=7.0610^{-3} \pm 0.3610^{-3}$ and $\pi=2.4010^{-3} \pm 0.3010^{-3}, \mathrm{U}=24, p=0.330$; values are given for $A$. chilense and $A$. transtasmanicum, respectively, Table 1). 
Within $A$. chilense, spatial clustering (SAMOVA; Table S4) revealed the existence of three genetically distinct groups of populations distributed in parapatry: one genetic cluster on the west coast of the North Island (the NW genetic cluster), another restricted to the Cook Strait (the Cook genetic cluster), and a third one distributed mainly along the eastern coasts of both North and South Islands, as well as the west coast of the South Island and Chatham Island (hereafter called the Eastern genetic cluster). Supporting the SAMOVA, the three genetic clusters were also recognized in the ribotype network (Fig. 1). The ribotype network obtained for $A$. chilense was reticulated (i.e., with unresolved mutational pathways), especially between ribotypes belonging to the NW genetic cluster (RAGL and SHEL, Fig. 1), showing evidence of homoplasy. However, except for ribotype r14 (sampled from GOLD, Guillemin et al. 2014), all ribotypes close to each other in the network were part of the same genetic cluster. No ribotypes were shared among clusters, suggesting a clear geographic pattern of genetic divergence. The network also revealed an unambiguous differentiation of the Eastern genetic cluster (E genetic cluster), with all ribotypes belonging to the E genetic cluster separated by a minimum of four mutational steps from the ones belonging to the Cook and NW genetic clusters. The central and most frequent ribotype of the E genetic cluster ( $(\mathrm{0} 01)$ was present in all 19 localities where this cluster was observed. The Cook and NW genetic cluster were not completely divergent, with ribotype r14 (sampled from the Cook Strait) being connected to ribotype r27 (sampled from the northernmost sampling site on the west coast of the North Island). Among the 45 ITS2 ribotypes retrieved in A. chilense, 37 (82\%) were private (i.e., present in only one population; 34 of which were unique ribotypes; Table S1) and distributed in a 
total of 13 populations. After rarefaction, gene and nucleotide diversities were the highest I in the two populations of the west coast of the North Island (SHEL and RAGL) and in one Chatham Island population (CHIS) (Table 1). In general, the genetic diversity was lower in the South Island than in the North Island, except for the north eastern populations WITI and OHOP, in which a single ribotype was found (Table 1). All the other monomorphic populations were located in the South Island (Table 1, Fig. 1).

The ribotype network obtained for A. transtasmanicum was reticulated, with up to six mutational steps depending on the selected pathways (Fig. 2). The ribotypes r01 and r05 were the most common, representing $69 \%$ and $17 \%$ of the samples sequenced, respectively (Fig. 2). The most frequent ribotype, r01, was present in all localities sampled in the Cook Strait and the North Island (WANG, OHIW, OHOP and MOIN), but was not found in the southern region of the South Island (CALA and HINA, Fig. 2). Private ribotypes were observed in all localities except OHOP (North Eastern region; Table 1; Table S2). The highest genetic diversity in A. transtasmanicum was observed in MOIN, located in the South Cook Strait region. No significant differences in nRrar were observed between North and South Islands (Table 1).

In $A$. chilense, the AMOVA showed that the genetic variance was principally explained by variation among genetic clusters $(\% \mathrm{var}=87.08, p<0.001$, Table 2$)$; while variation among populations within genetic clusters was much lower, but still significant (\%var $=6.58, p<0.001$; Table 2$)$. Similarly, biogeographical regions were significantly differentiated (\%var $=67.61, p<0.001$, Table 3$)$ and the variation among populations within bioregion was still significant even though lower (\%var=20.69, $p<0.001$; Table 3). In $A$. 
transtasmanicum, the AMOVA showed that most genetic variance was explained by the variance among populations within a bioregion $(\% \mathrm{var}=45.85, p<0.001)$, while the genetic variance among bioregions was non-significant (\%var= $15.19, p=0.46$, Table 4).

No significant isolation by distance was detected in both Agarophyton species ( $A$. chilense and A. transtasmanicum; $\mathrm{r}^{2}=-0.049, \mathrm{p}=0.65$ and $\mathrm{r}^{2}=0.544, p=0.07$, respectively).

\section{Historical demography}

| For A. chilense, all three genetic clusters showed a unimodal mismatch distribution fitting the spatial population expansion model (Fig. 3A; hypothesis of spatial expansion could not be rejected, SSD values ranging from 0.0003 to $0.0453, p>0.05$, Table 5). This was further supported by the negative values obtained for the Fu's Fs and Tajima's D tests $(\mathrm{Fs}=-5.92, p<0.01 ; \mathrm{D}=-0.76, \mathrm{p}=0.22$ for the NW genetic cluster; $\mathrm{Fs}=-7.72, p<0.001$ and $\mathrm{D}=-2.43, p<0.001$ for the Cook genetic; $\mathrm{Fs}=-3.40, p<0.001$ and $\mathrm{D}=-2.20, p<0.001$ for the E genetic cluster; Table 5). The BSP analysis for the E genetic cluster showed a demographic growth that started at the end of the Last Glacial Maximum (LGM, around 18,000-20,000 years ago, Fig. 3B), whereas no evidence of clear demographic change emerged for the Cook and NW genetic cluster.

For A. transtasmanicum, the mismatch distribution was bimodal (Fig. 3A). Nonsignificant values were obtained for the Fu's Fs and Tajima's D tests (Table 5), and the BSP analysis showed a demographic growth that also started at the end of the LGM (Fig. 3B).

Confidence intervals were large in all BSP analyses, damping most trends in estimated population size (Fig. 3B). Indeed, shifts in the BSP barely reached the 95\% 
credibility interval even in $A$. chilense E genetic cluster and A. transtasmanicum. These results should be interpreted with caution since a slight increase in population size in a BSP could be an artifact of random sampling by the Markov Chain Monte Carlo (MCMC) during gene genealogy reconstruction and not necessarily the result of historical demographic size changes (Ho and Shapiro 2011).

Agarophyton species diagnostic molecular tool

5P-COI sequences for 22 specimens of $A$. chilense and nine specimens of $A$. transtasmanicum revealed 51 fixed differences between the two Agarophyton species (GenBank accession numbers MN145983-MN146013). No variability was detected among the $A$. transtasmanicum individuals, while two polymorphic sites and three haplotypes were detected in A. chilense. Amplifications of the COI using the two sets of multiplex PCR primers provided a direct identification of the two Agarophyton species with $100 \%$ accuracy (Fig. 4). Whatever the primer combination used (Agarophyton_COI_F / Agarophyton_COI_R / Agarophyton_chilense_COI_F or Agarophyton_COI_F / Agarophyton_COI_R / Agarophyton_transtasmanicum_COI_F), the internal control amplification products (of 160bp) were always positive (Fig. 4).

\section{DISCUSSION}

The present study reveals important differences between Agarophyton chilense and A. transtasmanicum in terms of species distribution and genetic structure, while genetic diversity and habitats colonized (rocky and muddy) by the two Agarophyton species were 
fairly similar. Indeed, $A$. chilense's distribution was continuous and extensive, including the North and South Islands, Stewart Island, and Chatham Island, and the species exhibited genetic discontinuities concordant with biogeographic transitions. The distribution of $A$. transtasmanicum was more restricted and patchier, but the species was found in both the North and South Islands. Both Agarophyton species were found attached to hard substrate and as drifting thalli in soft-bottom habitats and had comparable genetic diversity at the population level. Species distribution patterns did not provide evidence of any clear ecological differences between the two species. We discuss our results in the light of the evolutionary history of $A$. transtasmanicum in New Zealand. Then we examine the potential outcome linked to the co-occurrence of the two species, and finally, we discuss the evolutionary history and biogeography of $A$. chilense in the archipelago.

Ancient presence of Agarophyton transtasmanicum in New Zealand

The early observations of $A$. transtasmanicum, limited to inlets located near Auckland city (in both the Manukau Harbour, corresponding to the Western North Island bioregion and the Waitemata Harbour, Orakei Basin, corresponding to the North Eastern bioregion), supported the hypothesis of a recent introduction of the species linked to anthropogenic activities (Wilcox et al. 2001, 2007, Nelson et al. 2015). Seaweeds transported by human activities usually show discontinuous distributions, with populations generally restricted to harbors or highly disturbed environments in the region of introduction (Trowbridge 1995, Smith et al. 2004). For example, unattached populations of the red alga Chondria harveyana are restricted to Porirua Harbour in the North Island, New 
Zealand, where it was introduced during the $19^{\text {th }}$ century by marine transport from

Tasmania (Adams 1983). In the same way, Gracilaria salicornia, introduced in Honolulu Harbour and Kaneohe Bay, Hawaii, in the 1970s, is still present with a distribution restricted to both bays three decades later (Smith et al. 2004). The extensive geographic survey of Agarophyton populations provided in the present study revealed a still patchy distribution, but with the presence of the species in two new bioregions (South Cook Strait and Southern). The present study also confirms the presence of A. transtasmanicum in the North Cook Strait (Whanganui and Manawatu River mouths, Preuss et al. 2020).

Agarophyton transtasmanicum's distribution range includes the sites of CALA and HINA located at the mouth of the Catlins River, a sparsely populated area with no present day passenger or freight boat services, suggesting limited contemporary impact of maritime transport as a possible source of colonizers. The Catlins region was settled by European immigrants in the 1840s and became a sawmilling hub for about 70 years from 1865 and on, with coastal vessels being the primary means of transport until the late 1800 s, and a number of vessels transporting timber to Dunedin and Christchurch from small ports that are no longer operating (Fortrose, Waikawa). Moreover, recently established populations of Gracilariales generally form vegetative mats embedded in soft substrates, whereas longestablished populations tend to be sexually reproductive populations attached to hard substrates by holdfasts as the result of spore settlement (Nettleton et al. 2013, KruegerHadfield et al. 2016). For example, 32 of the 35 sites where the invasive $A$. vermiculophyllum was collected in its recently introduced range (Europe and North America) were composed exclusively of unattached thalli embedded in soft substrate 
(Krueger-Hadfield et al. 2016). This was not the case in A. transtasmanicum for which half

| the sampled populations of the present study were attached to solid substrates, suggesting a regular occurrence of sexual reproduction in New Zealand. Samples from Manukau Harbour collected by Wilcox et al. (2001) were also reported as attached to cobble substrates. Taken together, these results are not in agreement with the hypothesis of a recent anthropogenic introduction of the species into the archipelago.

A low genetic diversity and absence of spatial genetic structure in a newly colonized region have also been reported as common characteristics of introduced seaweeds when compared to the region of origin (Kim et al. 2010, Le Cam et al. 2019). Such a genetic pattern is generally attributed to founder effects, linked to the arrival of a few individuals and the rapid expansion in the introduced range (Pérez et al. 2006, Kim et al. 2010, Lejeusne et al. 2011). The present study only focused on New Zealand's $A$. transtasmanicum populations, and no comparison with other regions where the species is present (Australia including Tasmania) was performed. However, when compared to the highly abundant and widely distributed $A$. chilense in the archipelago, no significant difference in genetic diversity was observed at the species or population level (Table 1).

Indeed, no significant differences between $A$. chilense and A. transtasmanicum were detected when comparing within-population ribotype or nucleotide diversity, nor between richness after rarefaction. In three of the four populations where both species coexist, $A$. transtasmanicum presented a higher genetic diversity than $A$. chilense (for both $\mathrm{H}$ and $\pi$ ) and one unique ribotype was observed in each species in the fourth population. Additionally, no clear differences in genetic diversity have been detected between Australia 
and New Zealand (but those results were only based on 13 ITS1 sequences in total; Preuss

et al. 2020). All results obtained to date suggest that $A$. transtasmanicum has a much longer demographic history in the New Zealand archipelago than expected for a recently introduced species. As previously suggested for other marine species (Neall and Trewick 2008, Waters 2008), we postulate that A. transtasmanicum could have colonized New Zealand from Australia at the end of the last glacial era as a result of trans-oceanic dispersal following main marine currents (flowing from west to east in the region). However, the species' patchy distribution and the existence of numerous ribotypes in the southern South Island may suggest a more complex history of $A$. transtasmanicum in the archipelago. Whether the species was present before the LGM or introduced more recently (but without a founder effect genetic signature) remains to be determined. A better coverage of the species' distribution range (along the coasts of Australia and Tasmania as well as within I New Zealand) is needed to infer the species' history more precisely.

Co-occurrence of Agarophyton chilense and A. transtasmanicum in New Zealand The co-occurrence of $A$. chilense and A. transtasmanicum in a single habitat brings an interesting perspective to the possible evolutionary origin of these species. First, coexistence of competing species within a specific ecological niche is generally considered a transient state, along a path that leads to the exclusion of one species (Olden et al. 2004, Gallardo et al. 2016). This competitive exclusion can be rapid when one species has a clear ecological advantage over the other. A potential advantage of $A$. transtasmanicum over $A$. chilense could come from the production of gigartinine in the former but not the latter, as 
proposed by Wilcox and collaborators $(2001,2007)$. However, $A$. transtasmanicum was restricted to a few and widely separated sites in the archipelago, while $A$. chilense was present throughout the range of sampled populations. Moreover, A. transtasmanicum never clearly dominated in regions where it co-existed with $A$. chilense (i.e., $54 \%$ of $A$. transtasmanicum in CALA, 30\% in HINA and OHOP). Therefore, A. transtasmanicum does not seem to be an overwhelmingly successful competitor in New Zealand.

It has been proposed that ecologically fairly similar species might actually coexist in the long term as a result of differences in micro-niches (MacDougall et al. 2009).

Overlapping distribution ranges between seaweed species generally involve a complete spatial segregation at the microscale (Peters et al. 2015, Muangmai et al. 2016, Montecinos et al. 2017). Subtle differences in temperature, wave exposure, or tidal height between the micro habitats of sister species have been associated with distribution range overlaps in algae (e.g., in red algae: Muangmai et al. 2015b, Muangmai et al. 2016; and in brown algae: Fraser et al. 2009a, Tellier et al. 2009). The red alga Bostrychia intricata shows spatial segregation related to wave exposure and tidal height between three cryptic lineages (N2, N4 and N5) around Moa Point in North Cook Strait, New Zealand (Muangmai et al. 2016), that was associated with subtle physiological differences previously found in these cryptic species in experimental studies (Muangmai et al. 2015b). Observations of the two species in the same ecological niche may suggest that allopatric speciation occurred in distant regions but in similar environments, in which case the current coexistence would result from secondary contact. Testing such hypotheses would require a global survey of the evolutionary history of Agarophyton, and the experimental assessment of the level of 
reproductive isolation and niche differentiation between the four species constituting the genus (Gurgel et al. 2018).

\section{Phylogeographic structure of Agarophyton chilense in New Zealand}

Three genetic clusters, distributed in parapatry, were detected in A. chilense and phylogeographic discontinuities were almost completely concordant with the described boundaries between bioregions (Ayers and Waters 2005, Ross et al. 2009, Shears et al. 2008). The main boundaries between genetic clusters observed in A. chilense in the present study included Cape Farewell, at the northern tip of the South Island (separating the Cook and the E genetic clusters) and Cape Reinga, at the northern tip of the North Island (separating the NW and the E genetic clusters). In New Zealand, a south/north and west/ east genetic structure has commonly been reported for marine organisms and matches the presence of biogeographic boundaries and oceanographic barriers to gene flow ( e.g., in marine invertebrates: Ross et al. 2009, Gardner et al. 2010; and in seaweeds: Muangmai et al. 2014, 2015a, Zuccarello and Martin 2016). The most prominent genetic break corresponds to the divergence among populations located around $42^{\circ} \mathrm{S}$, at the north of the South Island near Cape Farewell (Ayers and Waters 2005, Goldstien et al. 2006, Ross et al. 2009). The origin of this break has been associated with the historical of sea-level changes which closed the Cook Strait region during glacial periods (most recently 15-24,000 years ago; Lewis et al. 1994), and may be maintained by a sharp present-day thermal gradient acting as an environmental barrier to gene flow (Ayers and Waters 2005, Goldstien et al. 2006). Several studies have also observed a west/east genetic divergence at the northern tip 
of the North Island (Jones et al. 2008, Ross et al. 2009, Veale and Lavery 2012), where the strong southward oceanic splits into the eastern and western arms of the Auckland Current, which may strongly limit gene flow across this region. Moreover, marine intrusion and tectonic events during the upper Miocene and Pliocene have affected the topography of the shoreline at the northern tip of the North Island (Stevens and Hogg 2004) and have also been proposed as the cause of the west/east genetic break at Cape Reinga (Cooper and Millener 1993, Waters and Craw 2006).

The distribution of the genetic diversity also reflects past demographic dynamics in A. chilense. For the E genetic cluster, demographic inferences were congruent among the ribotype network, neutrality tests, mismatch distribution, and BSP analysis, and supported a scenario of postglacial expansion. The populations AHUR, PARE, PAUA, and SCOR, all located in the North Island, had the highest levels of genetic diversity within the E genetic cluster, suggesting that glacial refugia might have been located in this region. However, a single ribotype was observed in the northernmost populations OHOP and WITI, limiting our capacity to draw clear conclusions. Demographic inferences were less congruent for the I NW and the Cook genetic clusters. The ribotype network of the Cook genetic cluster had a star-like shape, suggesting a recent demographic expansion, which was further supported by the neutrality tests and a mismatch distribution fitting a geographic expansion model. However, the BSP analysis did not support any significant demographic change. This latter result may be attributed to the reduced number of sampled individuals and variability of the genetic marker (ITS2), which limit the statistical power of the Bayesian inference (Ho and Shapiro 2011, Grant et al. 2012, Grant 2015). It is possible that a geographically restricted 
demographic expansion (maybe after the LGM), from a local resilient population established on the western side of the Cook Strait, explains the distribution range and genetic diversity encountered in the Cook genetic cluster. The network structure of the NW genetic cluster is reticulated and rather suggested demographic stability. However, Tajima's and Fu's tests detected an excess of low frequency ribotypes (expected under rapid demographic expansion, but only the Fu test was statistically significant), and the BSP analysis suggested a mild demographic growth in the past 100,000 years, although with poor statistical confidence. These discrepancies are more difficult to explain. However, the shape of the genealogy evidenced in the ribotype network suggested that the various unique ribotypes observed in the region were not the product of recent mutations from an ancestral or founder ribotype. The higher genetic diversity (nRrar, $\mathrm{H}$, and $\pi$ ) observed in SHEL and RAGL compared to other more southerly and easterly populations further suggested that the NW population may have been demographically resilient during the LGM.

The LGM is considered one of the most important Quaternary events that has shaped the geographical distribution and genetic diversity patterns of terrestrial and marine species (Hewitt 2000, 2004, Maggs et al. 2008, Marko et al. 2010). In marine organisms, including seaweeds, a reduction of genetic diversity from lower to higher latitudes has commonly been observed, matching theoretical expectations from recolonization events among deglaciated areas at the end of the LGM (Australia: Fraser et al. 2009c; New Zealand: Macaya and Zuccarello 2010, Buchanan and Zuccarello 2012, Muangmai et al. 2015a; Chile: Montecinos et al. 2012, Guillemin et al. 2016). The same pattern was observed in A. chilense, reinforcing the hypothesis of a strong impact of the glacial- 
interglacial cycles on the dynamics of South Island marine populations. The statistical limitations of using a single genetic marker, impeded clear conclusions about the locations of glacial refugia, recolonization routes, and the timing of demographic changes and range shifts. Further studies, using more polymorphic (e.g., microsatellites markers; Assis et al. 2016) or numerous (e.g., Single Nucleotide Polymorphisms, SNPs; Vendrami et al. 2019) molecular markers will be needed to better infer the evolutionary history of $A$. chilense in New Zealand.

\section{CONCLUSIONS}

This study revealed the coexistence of two Agarophyton species in several widely separated locations in New Zealand. The species had similar genetic diversity at the local scale and occupied hard and soft bottom habitats. Agarophyton chilense presented an extensive distribution, with genetic discontinuities in agreement with the biogeographic structure of New Zealand's coasts and the historical changes associated with glacialinterglacial cycles. Ribotype r01, the most commonly sampled in Chile (Guillemin et al. 2014), dominated in all New Zealand localities where the E genetic cluster was present (this included the east coasts of both North and South Islands, as well as the western coast of the South Island and Chatham Island). While the results obtained in the present study

\section{corroborated the hypothesized colonization of South America from New Zealand}

(Guillemin et al. 2014) it provides little additional precision about the origin of the founders and the oceanic processes associated with the transoceanic transport of the algae.

Contrastingly, the distribution of genetic diversity in A. transtasmanicum did not match any 
clear biogeographic or historical feature, and it is difficult to draw conclusions about the evolutionary history of the species in New Zealand. The coexistence of the two species however raises several interesting questions about competitive exclusion, niche differentiation, and the effectiveness of the reproductive barriers discussed above. Lastly, the new molecular tool developed here allows quick and easy identification of the two Agarophyton species. It represents a useful tool for future monitoring of eventual changes in the species' distributions and in the execution of common-garden or transplant experiments needed to address open questions.

DATA SHARING AND DATA ACCESSIBILITY: The authors confirm that all data underlying the findings are fully available without restriction. Sequences are available in GenBank (accession numbers: MN145944 to MN145972 and MN145973 to MN145982).

AUTHOR CONTRIBUTION: MLG and WAN conceived the project; MLG, SM, OH and VR generated molecular data sets; OH performed the analyses; OH, MLG and SF drafted the manuscript; all authors contributed to discussions resulting in the final manuscript and edited the manuscript.

CONFLICT OF INTEREST DISCLOSURE: No potential conflict of interest was reported by the authors.

ACKNOWLEDGEMENTS: This work was supported by FONDECYT Regular 
Grant\#1170541 (CONICYT, Chile). MP and GZ were supported by Victoria University of

Wellington, WAN by NIWA SSIF funding (Coasts and Oceans Research Programme 2, Marine Biological Resources) and OH by BECA DOCTORADO NACIONAL Grant\#

21171226 (CONICYT, Chile). The staff of the herbarium of the Museum of New Zealand Te Papa Tongarewa (WELT) are thanked for their assistance. Special thanks goes to the National Institute of Water and Atmospheric Research (NIWA) in Wellington and Portobello Marine Laboratory in Dunedin who graciously provided research facilities.

\section{REFERENCE}

Adams, N.M. 1983. Checklist of marine algae possibly naturalised in New Zealand. New Zeal. J. Bot. 21: 1-2.

Assis, J., Coelho, N.C., Lamy, T., Valero, M., Alberto, F. \& Serrão, E.Á. 2016. Deep reefs are climatic refugia for genetic diversity of marine forests. J. Biogeogr. 43:833-44.

Ayers, K.L. \& Waters, J.M. 2005. Marine biogeographic disjunction in central New Zealand. Mar. Biol. 147:1045-52.

Bandelt, H.J., Forster, P. \& Röhl, A. 1999. Median-joining networks for inferring intraspecific phylogenies. Mol. Biol. Evol. 16:37-48.

Buchanan, J. \& Zuccarello, G.C. 2012. Decoupling of short- and long-distance dispersal pathways in the endemic New Zealand seaweed Carpophyllum maschalocarpum (Phaeophyceae, Fucales). J. Phycol. 48:518-29.

Buschmann, A.H., Correa, J.A., Westermeier, R., Hernández-González, M.D.C. \& Norambuena, R. 2001. Red algal farming in Chile: A review. Aquaculture. 194:203- 
Byrne, K., Zuccarello, G.C., West, J., Liao, M.L. \& Kraft, G.T. 2002. Gracilaria species (Gracilariaceae, Rhodophyta) from southeastern Australia, including a new species, Gracilaria perplexa sp. nov.: Morphology, molecular relationships and agar content. Phycol. Res. 50:295-311.

Candia, A., González, M.A., Montoya, R., Gómez, P. \& Nelson, W. 1999. Comparison of ITS RFLP patterns of Gracilaria (Rhodophyceae, Gracilariales) populations from Chile and New Zealand and an examination of interfertility of Chilean morphotypes. $J$. Appl. Phycol. 11:185-93.

Cohen, S., Faugeron, S., Martínez, E.A., Correa, J.A., Viard, F., Destombe, C. \& Valero, M. 2004. Molecular identification of two sibling species under the name Gracilaria chilensis (Rhodophyta, Gracilariales). J. Phycol. 40:742-7.

Cooper, R.A. \& Millener, P.R. 1993. The New Zealand biota: Historical backround and new research. Trends Ecol. Evol. 8:429-32.

Coyer, J.A., Peters, A.F., Hoarau, G., Stam, W.T. \& Olsen, J.L. 2002. Inheritance patterns of ITS1, chloroplasts and mitochondria in artificial hybrids of the seaweeds Fucus serratus and F. evanescens (Phaeophyceae). Eur. J. Phycol. 37:173-8.

Cooper, R.A. \& Millener, P.R. 1993. The New Zealand biota: Historical background and new research. Trends Ecol. Evol. 8: 429-433

Dupanloup, I., Schneider, S. \& Excoffier, L. 2002. A simulated annealing approach to define the genetic structure of populations. Mol. Ecol. 11(12): 2571-2581.

Drummond, A.J., Suchard, M.A., Xie, D. \& Rambaut, A. 2012. Bayesian phylogenetics 
with BEAUti and the BEAST 1.7. Mol. Biol. Evol. 29:1969-73.

Excoffier, L. \& Lischer, H.E.L. 2010. Arlequin suite ver 3.5: A new series of programs to perform population genetics analyses under Linux and Windows. Mol. Ecol. Resour. $10: 564-7$.

Excoffier, L., Smouse, P.E. \& Quattro, J.M. 1992. Analysis of molecular variance inferred from metric distances among DNA haplotypes: Application to human mitochondrial DNA restriction data. Genetics. 131:479-91.

Fraser, C.I., Hay, C.H., Spencer, H.G. \& Waters, J.M. 2009a. Genetic and morphological analyses of the southern bull kelp Durvillaea antarctica (Phaeophyceae: Durvillaeales) in New Zealand reveal cryptic species. J. Phycol. 45:436-43.

Fraser, C.I, Nikula, R., Spencer, H.G. \& Waters, J.M. 2009b. Kelp genes reveal effects of subantarctic sea ice during the Last Glacial Maximum. Proc. Natl. Acad. Sci. U. S. A. 106: $3249-3253$

Fraser, C.I., Spencer, H.G. \& Waters, J.M. 2009c. Glacial oceanographic contrasts explain phylogeography of Australian bull kelp. Mol. Ecol. 18:2287-96.

Fraser, C.I., Zuccarello, G.C., Spencer, H.G., Salvatore, L.C., Garcia, G.R. \& Waters, J.M. 2013. Genetic affinities between trans-oceanic populations of non-buoyant macroalgae in the high latitudes of the southern hemisphere. PLoS One. 8:e69138.

Fu, Y.X. 1997. Statistical tests of neutrality of mutations against population growth, hitchhiking and background selection. Genetics. 147:915-25.

Gallardo, B., Clavero, M., Sánchez, M.I., \& Vilà, M. 2016. Global ecological impacts of invasive species in aquatic ecosystems. Glob. Change Biol. 22(1), 151-163. 
Gardner, J.P., Bell, J., Constable, H.B., Hannan, D., Ritchie, P. \& Zuccarello, G. 2010. Multi-species coastal marine connectivity : A literature review with recommendations for further research. New Zeal. Aquat. Environ. Biodivers. Rep. 58, 1-47.

Goff, L.J. \& Moon, D.A. 1993. PCR amplification of nuclear and plastid genes from algal herbarium specimens and algal spores. J. Phycol. 29:381-4.

Goff, L.J., Moon, D.A. \& Coleman, A.W. 1994. Molecular delineation of species and species relationships in the red algal agarophytes Gracilariopsis and Gracilaria (Gracilariales). J. Phycol. 30:521-37.

Goldstien, S.J., Schiel, D.R. \& Gemmell, N.J. 2006. Comparative phylogeography of coastal limpets across a marine disjunction in New Zealand. Mol. Ecol. 15:3259-68.

Guillemin, M., Valero, M., Tellier, F., Macaya, E.C., Destombe, C. \& Faugeron, S. 2016. Phylogeography of seaweeds in the South East Pacific. Complex evolutionary processes along a latitudinal gradient. $251-277 \mathrm{pp}$.

Guillemin, M.L., Faugeron, S., Destombe, C., Viard, F., Correa, J.A. \& Valero, M. 2008. Genetic variation in wild and cultivated populations of the haploid- diploid red alga Gracilaria chilensis: How farming practices favor asexual reproduction and heterozygosity. Evolution. 62:1500-19.

Guillemin, M.L., Valero, M., Faugeron, S., Nelson, W. \& Destombe, C. 2014. Tracing the trans-Pacific evolutionary history of a domesticated seaweed (Gracilaria chilensis) with archaeological and genetic data. PLoS One. 9:1-17.

Gurgel, C.F.D., Norris, J.N., Schmidt, W.E., Le, H.N. \& Fredericq, S. 2018. Systematics of the Gracilariales (Rhodophyta) including new subfamilies, tribes, subgenera, and two 
new genera, Agarophyton gen. nov. and Crassa gen. nov. Phytotaxa. 374:1-23.

Grant, W.S. 2015. Problems and cautions with sequence mismatch analysis and Bayesian skyline plots to infer historical demography. J. Heredity, 106(4), 333-346.

Grant, W.S., Liu, M., Gao, T., \& Yanagimoto, T. 2012. Limits of Bayesian skyline plot analysis of mtDNA sequences to infer historical demographies in Pacific herring (and other species). Mol. Phylogenet. Evol., 65(1), 203-212.

Hammann, M., Wang, G., Rickert, E., Boo, S.M. \& Weinberger, F. 2013. Invasion success of the seaweed Gracilaria vermiculophylla correlates with low palatibility. Mar. Ecol. Prog. Ser. 486:93-103.

Hewitt, G. 2000. The genetic legacy of the quaternary ice ages. Nature. 405:907-13.

Hewitt, G.M. 2004. Genetic consequences of climatic oscillations in the Quaternary. Philos. Trans. R. Soc. B Biol. Sci. 359:183-95.

Ho, S.Y.W., Lanfear, R., Bromham, L., Phillips, M.J., Soubrier, J., Rodrigo, A.G. \& Cooper, A. 2011. Time-dependent rates of molecular evolution. Mol. Ecol. 20:3087-101.

Ho, S.Y., \& Shapiro, B. 2011. Skyline-plot methods for estimating demographic history from nucleotide sequences. Mol. Ecol. Resour., 11(3), 423-434.

Hu Z-M. \& Lopez-Bautista, J. 2014. Adaptation mechanisms and ecological consequences of seaweed invasions: A review case of agarophyte Gracilaria vermiculophylla. Biol. Invasions. 16:967-76.

Jones, T.C., Gemmill, C.E.C. \& Pilditch, C.A. 2008. Genetic variability of New Zealand seagrass (Zostera muelleri) assessed at multiple spatial scales. Aquat. Bot. 88:39-46.

Kain, J.M. \& Destombe, C. 1995. A review of the life history, reproduction and phenology 
of Gracilaria. J. Appl. Phycol. 7:269-81.

Keane, T.M., Creevey, C.J., Pentony, M.M., Naughton, T.J. \& Mclnerney, J.O. 2006.

Assessment of methods for amino acid matrix selection and their use on empirical data shows that ad hoc assumptions for choice of matrix are not justified. BMC Evol. Biol. $6: 1-17$.

Kim, J.K., Yarish, C. \& Pereira, R. 2016. Tolerances to hypo-osmotic and temperature stresses in native and invasive species of Gracilaria (Rhodophyta). Phycologia. 55:257-64.

Kim, S.Y., Weinberger, F. \& Boo, S.M. 2010. Genetic data hint at a common donor region for invasive Atlantic and Pacific populations of Gracilaria vermiculophylla (Gracilariales, Rhodophyta). J. Phycol. 46:1346-9.

Krueger-Hadfield, S.A., Kollars, N.M., Byers, J.E., Greig, T.W., Hammann, M., Murray, D.C., Murren, C.J., Strand, A.E., Terada, R., Weinberger, F. \& Sotka, E.E. 2016. Invasion of novel habitats uncouples haplo-diplontic life cycles. Mol. Ecol. 25:380116.

Larsson, A. 2014. AliView: A fast and lightweight alignment viewer and editor for large datasets. Bioinformatics. 30:3276-8.

Lewis, K.B., Carter, L. \& Davey, F.J. 1994. The opening of Cook Strait: Interglacial tidal scour and aligning basins at a subduction to transform plate edge. Mar. Geol. 116: $293-312$.

Laycock, M.V. \& Craigie, J.S. 1977. The occurrence and seasonal variation of gigartinine and L-citrullinyl-L-arginine in Chondus crispus Stackh. Can. J. Biochem. 55:27-30. 
Le Cam, S., Daguin-Thiébaut, C., Bouchemousse, S., Engelen, A.H., Mieszkowska, N. \& Viard, F. 2019. A genome-wide investigation of the worldwide invader Sargassum muticum shows high success albeit (almost) no genetic diversity. Evol. Appl. 0-1.

Lejeusne, C., Bock, D.G., Therriault, T.W., MacIsaac, H.J. \& Cristescu, M.E. 2011. Comparative phylogeography of two colonial ascidians reveals contrasting invasion histories in North America. Biol. Invasions. 13:635-50.

Macaya, E.C. \& Zuccarello, G.C. 2010. Genetic structure of the giant kelp Macrocystis pyrifera along the Southeastern Pacific. Mar. Ecol. Prog. Ser. 420:103-12.

McCarthy, C. 1997. Chromas, Version 1.41. Brisbane, Queensland: Griffith University.

McCulloch, G.A. \& Waters, J.M. 2019. Phylogenetic divergence of island biotas: Molecular dates, extinction, and "relict" lineages. Mol. Ecol. 28(19), 4354-4362.

McDowall, R.M. 2008. Process and pattern in the biogeography of New Zealand-a global microcosm? J. Biogeogr. 35(2), 197-212.

MacDougall, A.S., Gilbert, B. \& Levine, J.M. 2009. Plant invasions and the niche. J. Ecol. 97:609-15.

Maggs, C.A., Castilho, R., Foltz, D., Henzler, C., Taimour, M., Olsen, J., Perez, K.E. Stam, W., Vainola, R., Viard, F. \& Wares, J. 2008. Evaluating signatures of glacial refugia for North Atlantic benthic marine taxa. Ecology. 89(11): S108-S122.

Marko, P.B., Hoffman, J.M., Emme, S.A., McGovern, T.M., Keever, C.C. \& Nicole Cox, L. 2010. The "expansion-contraction" model of Pleistocene biogeography: Rocky shores suffer a sea change? Mol. Ecol. 19:146-69.

Montecinos, A., Broitman, B.R., Faugeron, S., Haye, P.A., Tellier, F. \& Guillemin, M.L. 
2012. Species replacement along a linear coastal habitat: Phylogeography and speciation in the red alga Mazzaella laminarioides along the south east pacific. BMC Evol. Biol. 12:97.

Muangmai, N., Fraser, C.I. \& Zuccarello, G.C. 2015a. Contrasting patterns of population structure and demographic history in cryptic species of Bostrychia intricata (Rhodomelaceae, Rhodophyta) from New Zealand. J. Phycol. 51:574-85.

Muangmai, N., Preuss, M., \& Zuccarello, G. C. 2015b. Comparative physiological studies on the growth of cryptic species of Bostrychia intricata (Rhodomelaceae, Rhodophyta) in various salinity and temperature conditions. Phycol. Res. 63(4), 300-306.

Muangmai, N., Von Ammon, U. \& Zuccarello, G.C. 2016. Cryptic species in sympatry: nonrandom small-scale distribution patterns in Bostrychia intricata (Ceramiales, Rhodophyta). Phycologia. 55(4), 424-430.

Muangmai, N., West, J.A. \& Zuccarello, G.C. 2014. Evolution of four Southern Hemisphere Bostrychia (Rhodomelaceae, Rhodophyta) species: Phylogeny, species delimitation and divergence times. Phycologia, 53(6), 593-601.

Neall, V.E. \& Trewick, S.A. 2008 The age and origin of the Pacific islands: A geological overview. Philos. Trans. R. Soc. Lond. B. Biol. Sci. 363: 3293-3308.

Neill, K. \& Nelson, W. 2019. New Zealand marine macroalgae species checklist. Version 1.7. The National Institute of Water and Atmospheric Research (NIWA). Checklist dataset https://doi.org/10.15468/ojjhcs.

Nelson, W.A. 1987. The New Zealand species of Gracilaria Greville (Rhodophyta, 
Gigartinales). New Zeal. J. Bot. 25:87-98.

Nelson, W.A. 1999. A revised checklist of marine algae naturalised in New Zealand. New Zeal. J. Bot. 37:355-9.

Nelson, W.A. 2012. Phylum Rhodophyta: Red algae. New Zealand inventory of biodiversity. Vol. 3. Kingdoms Bacteria, Protozoa, Chromista, Plantae, Fungi. Pp. $327-346$

Nelson, W.A. \& Duffy, C.A.J. 1991. Chnoospora minima (Phaeophyta) in Port Underwood, Marlborough - a curious new algal record for New Zealand. New Zeal. J. Bot. 29:3414.

Nelson, W.A., Neill, K.F. \& D'Archino, R. 2015. When seaweeds go bad: An overview of outbreaks of nuisance quantities of marine macroalgae in New Zealand. New Zeal. J. Mar. Freshw. Res. 49:472-91.

Nettleton, J.C., Mathieson, A.C., Thornber, C., Neefus, C.D. \& Yarish, C. 2013. Introduction of Gracilaria vermiculophylla (Rhodophyta, Gracilariales) to New England, USA: Estimated arrival times and current distribution. Rhodora. 115:28-41.

Olden, J.D., Poff, N.L., Douglas, M.R., Douglas, M.E. \& Fausch, K.D. 2004. Ecological and evolutionary consequences of biotic homogenization. Trends Ecol. Evol. 19(1), $18-24$

Pérez, J.E., Nirchio, M., Alfonsi, C. \& Muñoz, C. 2006. The biology of invasions: The genetic adaptation paradox. Biol. Invasions. 8:1115-21.

Peters, A.F., Couceiro, L., Tsiamis, K., Küpper, F.C. \& Valero, M. 2015. Barcoding of cryptic stages of marine brown algae isolated from incubated substratum reveals high 
diversity in Acinetosporaceae (Ectocarpales, Phaeophyceae). Cryptogam. Algol. 36:329.

Petit, R., Mousadik, A.E. \& Ponst, O. 1998. Identifying basis of populations markers for consevation on the genetic markers. Conserv. Biol. 12:844-55.

Preuss, M., Muangmai, N., Nelson, W.A., Guillemin, M.L., West, J. \& Zuccarello, G.C. 2020. A new species of Agarophyton, Agarophyton transtasmanicum sp. nov., from Australia and New Zealand. Phycologia. 1-8.

R Core Team. 2019. R: A language and environment for statistical computing. $R$ Foundation for Statistical Computing, Vienna, Austria. URL http://www.Rproject.org/

Ray, N., Currat, M. \& Excoffier, L. 2003. Intra-deme molecular diversity in spatially expanding populations. Mol. Biol. Evol. 20:76-86.

Ross, P.M., Hogg, I.D., Pilditch, C.A. \& Lundquist, C.J. 2009. Phylogeography of New Zealand's coastal benthos. New Zeal. J. Mar. Freshw. Res. 43:1009-27.

Rozas, J., Sánchez-DelBarrio, J.C., Messeguer, X. \& Rozas, R. 2003. DnaSP, DNA polymorphism analyses by the coalescent and other methods. Bioinformatics. 19:2496-7.

Saunders, G.W. 2005. Applying DNA barcoding to red macroalgae: A preliminary appraisal holds promise for future applications. Philos. Trans. R. Soc. B. 360:1879-88.

Santelices, B. \& Doty, M.S. 1989. A review of Gracilaria farming. Aquaculture. 78:95133.

Sharma, P.P. \& Wheeler, W.C. 2013. Revenant clades in historical biogeography: The geology of New Zealand predisposes endemic clades to root age shifts. J. Biogeogr. 
40: 1609-1618.

Shears, N.T., Smith, F., Babcock, R.C., Duffy, C.A.J. \& Villouta, E. 2008. Evaluation of biogeographic classification schemes for conservation panning: Applcation to New Zealand's coastal marine environmnet. Conserv. Biol. 22:467-81.

Smith, J.E., Hunter, C.L., Conklin, E.J., Most, R., Sauvage, T., Squair, C. \& Smith, C.M. 2004. Ecology of the invasive red alga Gracilaria salicornia (Rhodophyta) on O'ahu, Hawai'i. Pacific Sci. 58:325-43.

Stevens, M.I. \& Hogg, I.D. 2004. Population genetic structure of New Zealand's endemic corophiid amphipods: Evidence for allopatric speciation. Biol. J. Linn. Soc. 81:11933.

Tajima, F. 1989. Statistical method for testing the neutral mutation hypothesis by DNA polymorphism. Genetics. 123:585-95.

Tellier, F., Tapia, J., Faugeron, S., Destombe, C. \& Valero, M. 2011. The Lessonia nigrescens species complex (Laminariales, Phaeophyceae) shows strict parapatry and complete reproductive isolation in a secondary contact zone. J. Phycol. 47:894-903.

Trowbridge, C.D. 1995. Establishment of the green alga Codium fragile ssp. tomentosoides on New Zealand rocky shores: Current distribution and invertebrate grazers. J. Ecol. 83:949.

Veale, A.J. \& Lavery, S.D. 2012. The population genetic structure of the waratah anemone (Actinia tenebrosa) around New Zealand. New Zeal. J. Mar. Freshw. Res. 46:523-36. Vendrami, D.L.J., De Noia, M., Telesca, L., Handal, W., Charrier, G., Boudry, P., EberhartPhillips, L. \& Hoffman, J.I. 2019. RAD sequencing sheds new light on the genetic 
structure and local adaptation of European scallops and resolves their demographic histories. Sci. Rep. 9:1-13.

Wallis, G.P. \& Jorge, F. 2018. Going under down under? Lineage ages argue for extensive survival of the Oligocene marine transgression on Zealandia. Mol. Ecol. 27(22), 4368-4396.

Waters, J.M. \& Craw, D. 2006. Goodbye Gondwana? New Zealand biogeography, geology, and the problem of circularity. Syst. Biol. 55(2), 351-356.

Waters, J.M. 2008. Driven by the West Wind Drift? A synthesis of southern temperate marine biogeography, with new directions for dispersalism. J. Biogeog. 35(3), 417-427.

Waters, J.M. \& Craw, D. 2006. Goodbye Gondwana? New Zealand biogeography, geology, and the problem of circularity. Syst. Biol. 55:351-6.

Waters, J.M. \& Roy, M.S. 2004. Phylogeography of a high-dispersal New Zealand sea-star: Does upwelling block gene-flow? Mol. Ecol. 13:2797-80.

Wattier, R., Dallas, J.F., Destombe, C., Saumitou-Laprade, P. \& Valero, M. 1997. Single locus microsatellites in Gracilariales (Rhodophyta): High level of genetic variability within Gracilaria gracilis and conservation in related species. J. Phycol. 33:868-80.

Wilcox, S.J., Barr, N., Broom, J., Furneaux, R.H. \& Nelson, W.A. 2007. Using gigartinine to track the distribution of an alien species of Gracilaria in New Zealand. J. Appl. Phycol. 19:313-23.

Wilcox, S.J., Bloor, S.J., Hemmingson, J.A., Furneaux, R.H. \& Nelson, W.A. 2001. The presence of gigartinine in a New Zealand Gracilaria species. J. Appl. Phycol. 13:409_ 
13.

Zuccarello, G.C. \& Martin, P. 2016. Phylogeography of the Lessonia variegata species complex (Phaeophyceae, Laminariales) in New Zealand. Algae, 31(2): 91-103.

Zuccarello, G. C. \& West, J. A. 2002. Phylogeography of the Bostrychia calliptera-B. pinnata complex (Rhodomelaceae, Rhodophyta) and divergence rates based on nuclear, mitochondrial and plastid DNA markers. Phycologia. 41(1): 49-60. 
Table 1: Position of sampling sites and indices of genetic diversity calculated for the nuclear marker ITS2 in Agarophyton chilense and A. transtasmanicum throughout the New Zealand archipelago. For each site, the abbreviation (code), the population type (attached or unattached) and the geographic coordinates are indicated. N: total number of sequences with the number of sequences added from Guillemin et al. (2014) in brackets; nR: number of ribotypes; nRrar: number of ribotypes corrected for unequal sample size after rarefaction method; H: gene diversity; $\pi$ : nucleotide diversity; S: number of polymorphic sites; Rpriv: number of private ribotypes; -: not estimated (in $\mathrm{N}<8$ ). aStandard deviations are in brackets. Bioregions (bold) were defined using the Coastal Biogeographic Regions Classification map provided in http://www.mfe.govt.nz/more/science-and-data/ classification-systems/marine-classification-systems.

\begin{tabular}{|c|c|c|c|c|c|c|c|c|c|c|c|c|c|c|}
\hline & & \multicolumn{7}{|c|}{$\begin{array}{c}\text { Agarophyton } \\
\text { chilense }\end{array}$} & \multicolumn{6}{|c|}{$\begin{array}{c}\text { Agarophyton } \\
\text { transtasmanicum }\end{array}$} \\
\hline $\begin{array}{l}\text { Site } \\
(\text { code })\end{array}$ & $\begin{array}{c}\text { Popul } \\
\text { ation } \\
\text { type }\end{array}$ & Position & $\mathrm{N}$ & $\begin{array}{c}\mathrm{nR} / \\
\mathrm{nRr} \\
\mathrm{ar}\end{array}$ & $\mathrm{H}^{\mathrm{a}}$ & $\begin{array}{c}\pi(. \\
\left.10^{-3}\right) \\
\text { a }\end{array}$ & $\mathrm{S}$ & $\begin{array}{l}\mathrm{R} \\
\mathrm{pr} \\
\text { iv }\end{array}$ & $\mathrm{N}$ & $\begin{array}{l}\mathrm{nR} / \\
\mathrm{nRr} \\
\text { ar }\end{array}$ & $\mathrm{H}^{\mathrm{a}}$ & $\begin{array}{c}\pi(. \\
\left.10^{-3}\right) \\
\text { a }\end{array}$ & $\mathrm{S}$ & $\begin{array}{l}\mathrm{R} \\
\mathrm{pr} \\
\text { iv }\end{array}$ \\
\hline $\begin{array}{c}\text { Western } \\
\text { North } \\
\text { Island }\end{array}$ & & & & & & & & & & & & & & \\
\hline $\begin{array}{c}\text { Shelly } \\
\text { Beach } \\
\text { (SHEL) }\end{array}$ & $\begin{array}{c}\text { Attac } \\
\text { hed }\end{array}$ & $\begin{array}{c}36^{\circ} 34^{\prime} \mathrm{S}, \\
174^{\circ} 22^{\prime} \\
\mathrm{E}\end{array}$ & $\begin{array}{l}2 \\
6\end{array}$ & $\begin{array}{c}7 / 3 \\
49\end{array}$ & $\begin{array}{c}0.8 \\
22 \\
(0.0 \\
37)\end{array}$ & $\begin{array}{l}3.24 \\
(0.0 \\
00)\end{array}$ & 9 & 3 & & & & & & \\
\hline
\end{tabular}




\begin{tabular}{|c|c|c|c|c|c|c|c|c|c|c|c|c|c|c|}
\hline $\begin{array}{l}\text { Raglan } \\
\text { (RAGL) }\end{array}$ & $\begin{array}{c}\text { Attac } \\
\text { hed }\end{array}$ & $\begin{array}{c}37^{\circ} 48^{\prime} \mathrm{S} \\
174^{\circ} 53^{\prime} \\
\mathrm{E}\end{array}$ & $\begin{array}{l}2 \\
4\end{array}$ & $\begin{array}{c}11 / \\
4.5 \\
2\end{array}$ & $\begin{array}{l}0.8 \\
77 \\
(0.0 \\
45)\end{array}$ & $\begin{array}{c}5.00 \\
(1.0 \\
4)\end{array}$ & 11 & 7 & & & & & & \\
\hline $\begin{array}{c}\text { North } \\
\text { Cook } \\
\text { Strait } \\
\end{array}$ & & & & & & & & & & & & & & \\
\hline $\begin{array}{c}\text { Whangan } \\
\text { ui } \\
\text { (WANG) }\end{array}$ & $\begin{array}{c}\text { Attac } \\
\text { hed }\end{array}$ & $\begin{array}{c}39^{\circ} 56^{\prime} \mathrm{S} \\
174^{\circ} 59^{\prime} \\
\mathrm{E}\end{array}$ & & & & & & & $\begin{array}{l}3 \\
0\end{array}$ & $\begin{array}{r}2 / 0 . \\
27\end{array}$ & $\begin{array}{l}0.0 \\
67 \\
(0 . \\
06 \\
1)\end{array}$ & $\begin{array}{c}0.13 \\
(0.1 \\
2)\end{array}$ & 1 & 1 \\
\hline $\begin{array}{c}\text { Paremata } \\
\text { (PARE) }\end{array}$ & $\begin{array}{c}\text { Attac } \\
\text { hed }\end{array}$ & $\begin{array}{c}41^{\circ} 06^{\prime} \mathrm{S} \\
174^{\circ} 52^{\prime} \\
\mathrm{E}\end{array}$ & $\begin{array}{l}3 \\
4 \\
(1 \\
4)\end{array}$ & $\begin{array}{c}2 / 0 . \\
94\end{array}$ & $\begin{array}{c}0.4 \\
01 \\
(0.0 \\
73)\end{array}$ & $\begin{array}{c}0.83 \\
(0.1 \\
5)\end{array}$ & 1 & 0 & & & & & & \\
\hline $\begin{array}{c}\text { Pauataha } \\
\text { nui } \\
\text { (PAUA) }\end{array}$ & $\begin{array}{l}\text { Unatt } \\
\text { ached }\end{array}$ & $\begin{array}{c}41^{\circ} 05^{\prime} \mathrm{S} \\
174^{\circ} 54^{\prime} \\
\mathrm{E}\end{array}$ & $\begin{array}{l}2 \\
8\end{array}$ & $\begin{array}{r}5 / 1 . \\
75\end{array}$ & $\begin{array}{c}0.5 \\
08 \\
(0.0 \\
96)\end{array}$ & $\begin{array}{c}0.14 \\
(0.3 \\
6)\end{array}$ & 5 & 3 & & & & & & \\
\hline $\begin{array}{c}\text { Scorchin } \\
\text { g Bay } \\
\text { (SCOR) }\end{array}$ & $\begin{array}{c}\text { Attac } \\
\text { hed }\end{array}$ & $\begin{array}{c}41^{\circ} 18^{\prime} \mathrm{S} \\
174^{\circ} 48^{\prime} \\
\mathrm{E}\end{array}$ & $\begin{array}{l}1 \\
5 \\
(1 \\
5)\end{array}$ & $\begin{array}{c}3 / 1 \\
51\end{array}$ & $\begin{array}{c}0.5 \\
14 \\
(0.1 \\
16)\end{array}$ & $\begin{array}{c}1.14 \\
(0.3 \\
0)\end{array}$ & 2 & 2 & & & & & & \\
\hline \multicolumn{15}{|l|}{$\begin{array}{c}\text { Eastern } \\
\text { North } \\
\text { Island } \\
\end{array}$} \\
\hline $\begin{array}{l}\text { Ahuriri } \\
\text { (AHUR) }\end{array}$ & $\begin{array}{c}\text { Attac } \\
\text { hed }\end{array}$ & $\begin{array}{c}39^{\circ} 28^{\prime} \mathrm{S} \\
176^{\circ} 53^{\prime} \\
\mathrm{E}\end{array}$ & $\begin{array}{l}1 \\
8\end{array}$ & $\begin{array}{c}4 / 1 . \\
86\end{array}$ & $\begin{array}{c}0.5 \\
75 \\
(0.1 \\
01)\end{array}$ & $\begin{array}{c}2.08 \\
(0.3 \\
9)\end{array}$ & 3 & 3 & & & & & & \\
\hline $\begin{array}{c}\text { North } \\
\text { Eastern }\end{array}$ & & & & & & & & & & & & & & \\
\hline
\end{tabular}




\begin{tabular}{|c|c|c|c|c|c|c|c|c|c|c|c|c|c|c|}
\hline $\begin{array}{l}\text { Whitiang } \\
\text { a (WITI) }\end{array}$ & $\begin{array}{c}\text { Attac } \\
\text { hed }\end{array}$ & $\begin{array}{c}36^{\circ} 50^{\prime} \mathrm{S}, \\
175^{\circ} 41^{\prime} \\
\mathrm{E}\end{array}$ & $\begin{array}{l}1 \\
4\end{array}$ & $\begin{array}{c}1 / 0 . \\
00\end{array}$ & 0 & 0 & 0 & 0 & & & & & & \\
\hline $\begin{array}{c}\text { Ohiwa } \\
\text { (OHIW) }\end{array}$ & $\begin{array}{l}\text { Unatt } \\
\text { ached }\end{array}$ & $\begin{array}{l}37^{\circ} 59^{\prime} \mathrm{S}, \\
177^{\circ} 11^{\prime} \mathrm{E}\end{array}$ & & & & & & & $\begin{array}{l}2 \\
9\end{array}$ & $\begin{array}{c}2 / 0 . \\
48\end{array}$ & $\begin{array}{l}0.1 \\
33 \\
(0 . \\
08 \\
1)\end{array}$ & $\begin{array}{c}0.27 \\
(0.1 \\
7)\end{array}$ & 1 & 2 \\
\hline $\begin{array}{c}\text { Ohope } \\
\text { (OHOP) }\end{array}$ & $\begin{array}{c}\text { Attac } \\
\text { hed }\end{array}$ & $\begin{array}{c}37^{\circ} 58^{\prime} \mathrm{S}, \\
177^{\circ} 04^{\prime} \\
\mathrm{E}\end{array}$ & $\begin{array}{l}1 \\
9\end{array}$ & $\begin{array}{c}1 / 0 . \\
00\end{array}$ & 0 & 0 & 0 & 0 & 8 & $\begin{array}{c}1 / 0 \\
00\end{array}$ & 0 & 0 & 0 & 0 \\
\hline $\begin{array}{l}\text { West } \\
\text { Coast } \\
\text { South } \\
\text { Island }\end{array}$ & & & & & & & & & & & & & & \\
\hline $\begin{array}{c}\text { Okari } \\
\text { River } \\
\text { (OKAR) }\end{array}$ & $\begin{array}{c}\text { Attac } \\
\text { hed }\end{array}$ & $\begin{array}{c}41^{\circ} 48^{\prime} \mathrm{S} \\
171^{\circ} 27^{\prime} \\
\mathrm{E}\end{array}$ & $\begin{array}{l}1 \\
9\end{array}$ & $\begin{array}{c}1 / 0 . \\
00\end{array}$ & 0 & 0 & 0 & 0 & & & & & & \\
\hline $\begin{array}{c}\text { South } \\
\text { Cook } \\
\text { Strait }\end{array}$ & & & & & & & & & & & & & & \\
\hline $\begin{array}{c}\text { Whangan } \\
\text { ui Inlet } \\
\text { (WAIN) }\end{array}$ & $\begin{array}{c}\text { Attac } \\
\text { hed }\end{array}$ & $\begin{array}{c}40^{\circ} 35^{\prime} \mathrm{S}, \\
172^{\circ} 37^{\prime} \\
\mathrm{E}\end{array}$ & $\begin{array}{l}2 \\
3 \\
(1 \\
1)\end{array}$ & $\begin{array}{c}4 / 1 \\
04\end{array}$ & $\begin{array}{c}0.2 \\
49 \\
(0.1 \\
16)\end{array}$ & $\begin{array}{c}0.54 \\
(0.2 \\
7)\end{array}$ & 3 & 3 & & & & & & \\
\hline $\begin{array}{c}\text { Golden } \\
\text { Bay } \\
\text { (GOLD) }\end{array}$ & $\begin{array}{c}\text { Attac } \\
\text { hed }\end{array}$ & $\begin{array}{c}40^{\circ} 48^{\prime} \mathrm{S} \\
172^{\circ} 48^{\prime} \\
\mathrm{E}\end{array}$ & $\begin{array}{c}8 \\
(8 \\
)\end{array}$ & $\begin{array}{c}2 / 1 . \\
00\end{array}$ & $\begin{array}{c}0.2 \\
50 \\
(0.1 \\
80)\end{array}$ & $\begin{array}{c}2.07 \\
(1.4 \\
9)\end{array}$ & 4 & 1 & & & & & & \\
\hline $\begin{array}{l}\text { Moutere } \\
\text { Inlet } \\
\text { (MOUT) }\end{array}$ & $\begin{array}{c}\text { Attac } \\
\text { hed }\end{array}$ & $\begin{array}{c}41^{\circ} 08^{\prime} \mathrm{S} \\
173^{\circ} 00^{\prime} \\
\mathrm{E}\end{array}$ & $\begin{array}{l}4 \\
9 \\
(1 \\
1)\end{array}$ & $\begin{array}{c}5 / 0 \\
50\end{array}$ & $\begin{array}{c}0.1 \\
58 \\
(0.0 \\
70)\end{array}$ & $\begin{array}{c}0.93 \\
(0.6 \\
5)\end{array}$ & 11 & 3 & & & & & & \\
\hline
\end{tabular}




\begin{tabular}{|c|c|c|c|c|c|c|c|c|c|c|c|c|c|c|}
\hline $\begin{array}{c}\text { Moutere } \\
\text { Inlet } \\
\text { (MOIN) }\end{array}$ & $\begin{array}{l}\text { Unatt } \\
\text { ached }\end{array}$ & $\begin{array}{c}41^{\circ} 08^{\prime} \mathrm{S} \\
173^{\circ} 00^{\prime} \\
\mathrm{E}\end{array}$ & & & & & & & $\begin{array}{l}1 \\
3\end{array}$ & $\begin{array}{c}5 / 2 \\
97\end{array}$ & $\begin{array}{l}0.7 \\
05 \\
(0 . \\
12 \\
2)\end{array}$ & $\begin{array}{c}3.77 \\
(0.6 \\
3)\end{array}$ & 4 & 2 \\
\hline $\begin{array}{c}\text { Momoran } \\
\text { gi Bay } \\
\text { (MOMO) }\end{array}$ & $\begin{array}{c}\text { Attac } \\
\text { hed }\end{array}$ & $\begin{array}{c}41^{\circ} 16^{\prime} \mathrm{S} \\
173^{\circ} 56^{\prime} \\
\mathrm{E}\end{array}$ & $\begin{array}{l}2 \\
0\end{array}$ & $\begin{array}{c}2 / 0 . \\
40\end{array}$ & $\begin{array}{c}0.1 \\
00 \\
(0.0 \\
88)\end{array}$ & $\begin{array}{c}0.21 \\
(0.1 \\
8)\end{array}$ & 1 & 1 & & & & & & \\
\hline \multicolumn{15}{|l|}{$\begin{array}{c}\text { Fiordlan } \\
\text { d }\end{array}$} \\
\hline $\begin{array}{c}\text { Fiordland } \\
\text { (CASS) }\end{array}$ & $\begin{array}{c}\text { Attac } \\
\text { hed }\end{array}$ & $\begin{array}{c}45^{\circ} 55^{\prime} \mathrm{S} \\
166^{\circ} 54^{\prime} \\
\mathrm{E}\end{array}$ & $\begin{array}{l}1 \\
7\end{array}$ & $\begin{array}{c}2 / 0 . \\
47\end{array}$ & $\begin{array}{c}0.1 \\
18 \\
(0.1 \\
01)\end{array}$ & $\begin{array}{c}0.24 \\
(0.2 \\
1)\end{array}$ & 1 & 1 & & & & & & \\
\hline $\begin{array}{c}\text { Riverton } \\
\text { (RIVE) }\end{array}$ & $\begin{array}{c}\text { Attac } \\
\text { hed }\end{array}$ & $\begin{array}{c}46^{\circ} 21^{\prime} \mathrm{S} \\
168^{\circ} 00^{\prime} \\
\mathrm{E}\end{array}$ & $\begin{array}{l}2 \\
0\end{array}$ & $\begin{array}{c}2 / 0 . \\
40\end{array}$ & $\begin{array}{c}0.1 \\
00 \\
(0.0 \\
88)\end{array}$ & $\begin{array}{c}0.21 \\
(0.1 \\
8)\end{array}$ & 1 & 1 & & & & & & \\
\hline \multicolumn{15}{|l|}{ Southern } \\
\hline $\begin{array}{c}\text { Stewart } \\
\text { Island } \\
\text { (STEW) }\end{array}$ & $\begin{array}{c}\text { Attac } \\
\text { hed }\end{array}$ & $\begin{array}{c}46^{\circ} 54^{\prime} \mathrm{S}, \\
168^{\circ} 08^{\prime} \\
\mathrm{E}\end{array}$ & $\begin{array}{l}3 \\
5 \\
(1 \\
7)\end{array}$ & $\begin{array}{r}2 / 0 . \\
23\end{array}$ & $\begin{array}{c}0.0 \\
57 \\
(0.0 \\
53)\end{array}$ & $\begin{array}{c}0.12 \\
(0.1 \\
1)\end{array}$ & 1 & 1 & & & & & & \\
\hline $\begin{array}{c}\text { Catlins } \\
\text { Lake } \\
\text { (CALA) }\end{array}$ & $\begin{array}{l}\text { Unatt } \\
\text { ached }\end{array}$ & $\begin{array}{c}46^{\circ} 28^{\prime} \mathrm{S} \\
169^{\circ} 38^{\prime} \\
\mathrm{E}\end{array}$ & $\begin{array}{l}1 \\
1\end{array}$ & $\begin{array}{r}1 / 0 . \\
00\end{array}$ & 0 & 0 & 0 & 0 & $\begin{array}{l}1 \\
3\end{array}$ & $\begin{array}{c}3 / 1 \\
84\end{array}$ & $\begin{array}{l}0.5 \\
90 \\
(0 . \\
12 \\
2)\end{array}$ & $\begin{array}{c}2.84 \\
(0.5 \\
3)\end{array}$ & 3 & 1 \\
\hline $\begin{array}{c}\text { Hinahina } \\
\text { (HINA) }\end{array}$ & $\begin{array}{c}\text { Attac } \\
\text { hed }\end{array}$ & $\begin{array}{c}46^{\circ} 28^{\prime} \mathrm{S} \\
169^{\circ} 40^{\prime} \\
\mathrm{E}\end{array}$ & $\begin{array}{l}2 \\
6\end{array}$ & $\begin{array}{r}4 / 0 . \\
92\end{array}$ & $\begin{array}{c}0.2 \\
22 \\
(0.1 \\
06)\end{array}$ & $\begin{array}{c}0.48 \\
(0.2 \\
4)\end{array}$ & 3 & 3 & 3 & $3 /-$ & $\begin{array}{l}1.0 \\
00 \\
(0 . \\
27 \\
2)\end{array}$ & $\begin{array}{c}2.69 \\
0 \\
(0.9 \\
0)\end{array}$ & 2 & 2 \\
\hline
\end{tabular}




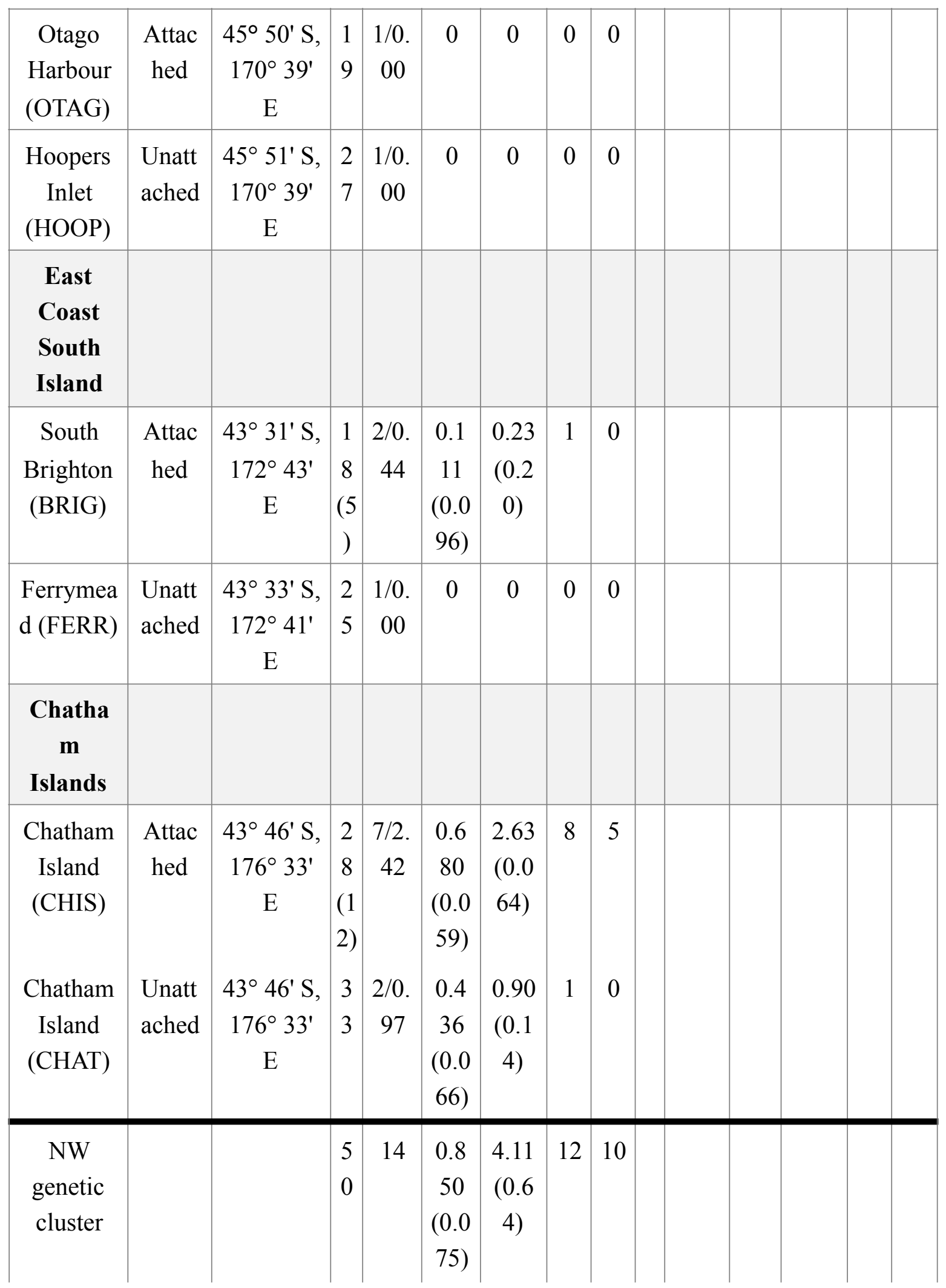




\begin{tabular}{|c|c|c|c|c|c|c|c|c|c|c|c|c|} 
Cook \\
genetic \\
cluster
\end{tabular}


Table 2: Analysis of molecular variance (AMOVA) of Agarophyton chilense for the ITS2 marker with hierarchical partitioning of variance among genetic clusters and among sites within genetic cluster. Genetic clusters were defined according to the SAMOVA results $($ NW genetic cluster $=$ SHEL and RAGL; Cook genetic cluster $=$ WAIN, MOUT, and GOLD; and E genetic cluster= WITI, OHOP, AHUR, PARE, PAUA, SCOR, MOMO, BRIG, FERR, OTAG, HOOP, CALA, HINA, STEW, RIVE, CASS, OKAR, CHAT, and CHIS, see Figure 1); d.f.: degree of freedom.

\begin{tabular}{ccccc}
\hline Source of variation & d.f. & \% variation & Fst & p-value \\
\hline $\begin{array}{c}\text { Among genetic clusters } \\
\text { Among sites within genetic } \\
\text { cluster }\end{array}$ & 21 & 87.08 & 0.87 & $<0.001$ \\
Residual & 632 & 6.34 & 0.51 & $<0.001$ \\
Total & 555 & - & - & - \\
\hline
\end{tabular}


Table 3: Analysis of molecular variance (AMOVA) of Agarophyton chilense for the ITS2 marker with hierarchical partitioning of variance among bioregions and among sites within bioregion. Bioregions were defined using the Coastal Biogeographic Regions Classification map provided in http://www.mfe.govt.nz/more/science-and-data/classification-systems/ marine-classification-systems (Western North Island= SHEL and RAGL; North Eastern= WITI and OHOP; North Cook Strait= PARE, PAUA, and SCOR; South Cook Strait= WAIN, MOUT, GOLD, and MOMO; Fiordland= CASS and RIVE; Southern= STEW, HINA, CALA, HOOP, and OTAG; East Coast South Island= FERR and BRIG; and Chatham Island= CHAT and CHIS, see Table 1); d.f.: degree of freedom. Localities of OKAR in West Coast South Island and AHUR in Eastern North Island were excluded from the analysis since only one site was sampled within each of these two bioregions (Table 1).

\begin{tabular}{ccccc}
\hline Source of variation & d.f. & \% variation & Fst & p-value \\
\hline Among bioregions & 7 & 67.61 & 0.68 & $<0.001$ \\
$\begin{array}{c}\text { Among sites within } \\
\text { bioregions }\end{array}$ & 14 & 20.69 & 0.64 & $<0.001$ \\
Residual & 497 & 11.70 & - & - \\
Total & 518 & - & - & - \\
\hline
\end{tabular}


Table 4: Analysis of molecular variance (AMOVA) of Agarophyton transtasmanicum for the ITS2 marker with hierarchical partitioning of variance among bioregions, among sites within bioregion and within sampling site. Bioregions were defined using the Coastal Biogeographic Regions Classification map provided in http://www.mfe.govt.nz/more/ science-and-data/classification-systems/marine-classification-systems. Localities from the Cook Strait were clumped in a region named North/South Cook Strait. Regions were: North Eastern $=$ OHIW and OHOP; North/South Cook Strait= WANG and MOIN; and Southern= HINA and CALA (see Table 1). d.f.: degree of freedom.

\begin{tabular}{ccccc}
\hline Source of variation & d.f. & \% variation & Fst & p-value \\
\hline Among bioregions & 2 & 15.19 & 0.15 & 0.46 \\
$\begin{array}{c}\text { Among sites within } \\
\text { bioregions }\end{array}$ & 1 & 45.85 & 0.54 & $<0.001$ \\
Residual & 90 & 38.96 & - & - \\
Total & 95 & - & - & - \\
\hline
\end{tabular}


Table 5: Test of historical demographic change based on ITS2 sequences of Agarophyton chilense and A. transtasmanicum. Each genetic cluster of $A$. chilense (defined according to the SAMOVA results) was treated independently. Significance of Tajima's D and Fu's FS tests and the goodness-of-fit for SSD were determined using 1000 bootstrap replicates in the software ARLEQUIN v 3.11 (Excoffier and Lisher 2010); § p-value $>0.05$ means the null hypothesis of sudden expansion cannot be rejected; SSD: sum of squared deviations.

\begin{tabular}{ccccc}
\hline & $\begin{array}{c}\text { A. chilense- } \\
\text { NW genetic } \\
\text { cluster }\end{array}$ & $\begin{array}{c}\text { A. chilense- } \\
\text { Cook genetic } \\
\text { cluster }\end{array}$ & $\begin{array}{c}\text { A. chilense- E } \\
\text { genetic cluster }\end{array}$ & $\begin{array}{c}\text { A. } \\
\text { transtasmanic } \\
\text { um }\end{array}$ \\
\hline $\begin{array}{c}\text { Tajima's D } \\
(\text { p-value })\end{array}$ & -0.76 & -2.43 & -2.20 & 0.94 \\
Fu's Fs & $(0.22)$ & $(<0.001)$ & $(<0.001)$ & $(0.83)$ \\
$($ p-value) & -5.92 & -7.72 & -3.40 & -3.37 \\
SSD & $(<0.01)$ & $(<0.001)$ & $(<0.001)$ & $(0.07)$ \\
$(p$-value) $\S$ & 0.0453 & 0.0011 & 0.0003 & 0.0208 \\
\hline
\end{tabular}



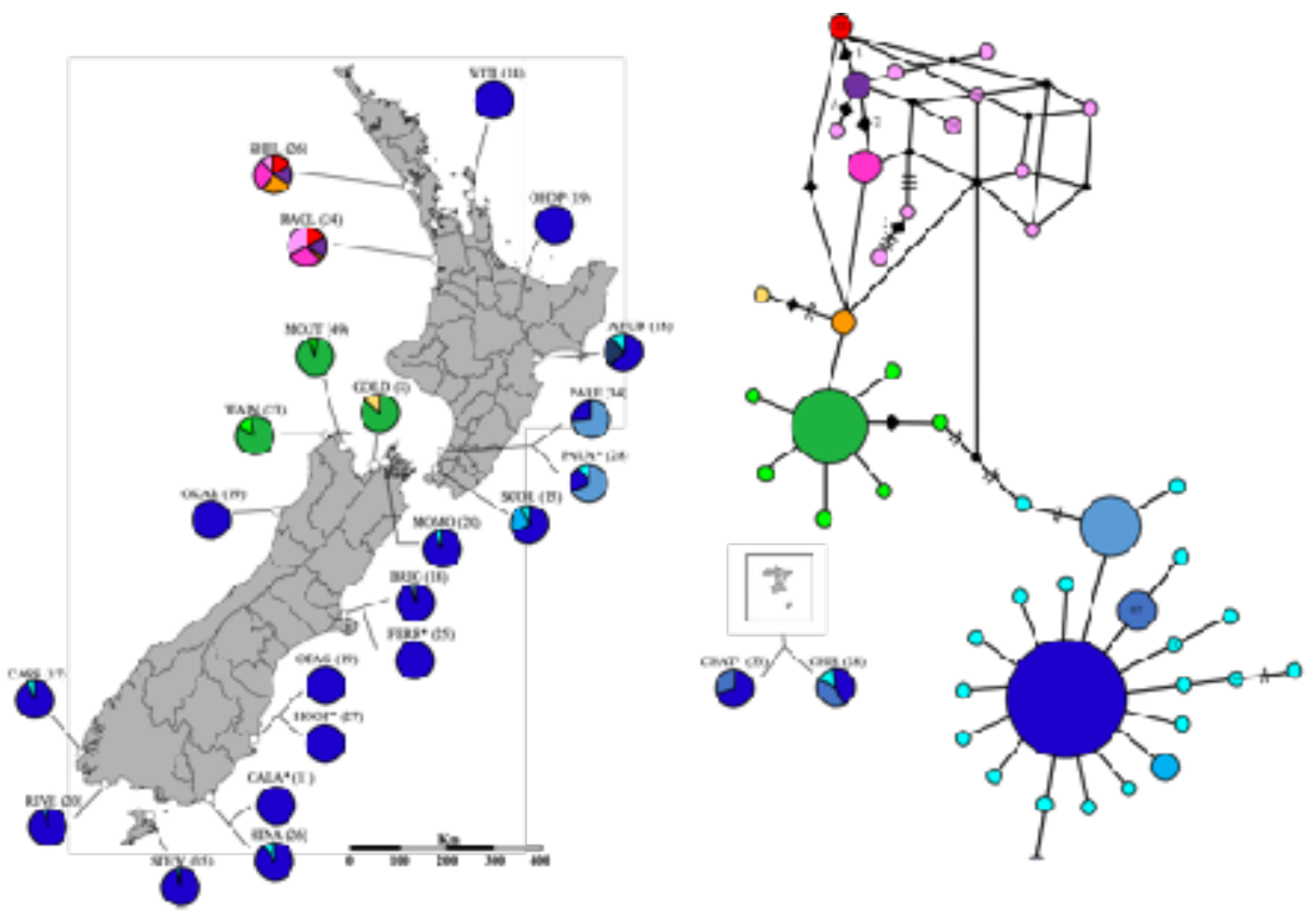

Figure 1: ITS2 ribotype distribution and ITS2 network including 556 sequences of Agarophyton chilense. Length of ITS2 sequences vary between 479 base pairs (bp) and 483 bp. Pie charts represent ribotype frequency in each sampling site, sequence number in each site is noted between parenthesis, colors correspond to the ones presented in the ITS2 network. In the network, circle sizes are proportional to the ribotype frequency and connection lengths correspond to mutation steps. For ribotypes separated by more than one mutational step, black bars represent the number of steps. Black diamond: indel, for each indel the number of bp is noted above. Black circle: hypothetical un-sampled ribotype. Rare and private ribotypes, in each genetic cluster, are represented by the same color for clarity. Ribotype r14, substantiating the ambiguous differentiation between Cook and NW genetic 
clusters is colored in yellow. Ribotype number as in Table S1 and S2. *: population of

I floating thalli; population abbreviations as in Table 1. Genetic clusters as defined by the SAMOVA are: NW genetic cluster= SHEL and RAGL; Cook genetic cluster $=$ WAIN, MOUT, and GOLD; and E genetic cluster= WITI, OHOP, AHUR, PARE, PAUA, SCOR, MOMO, BRIG, FERR, OTAG, HOOP, CALA, HINA, STEW, RIVE, CASS, OKAR, CHAT, and CHIS. 

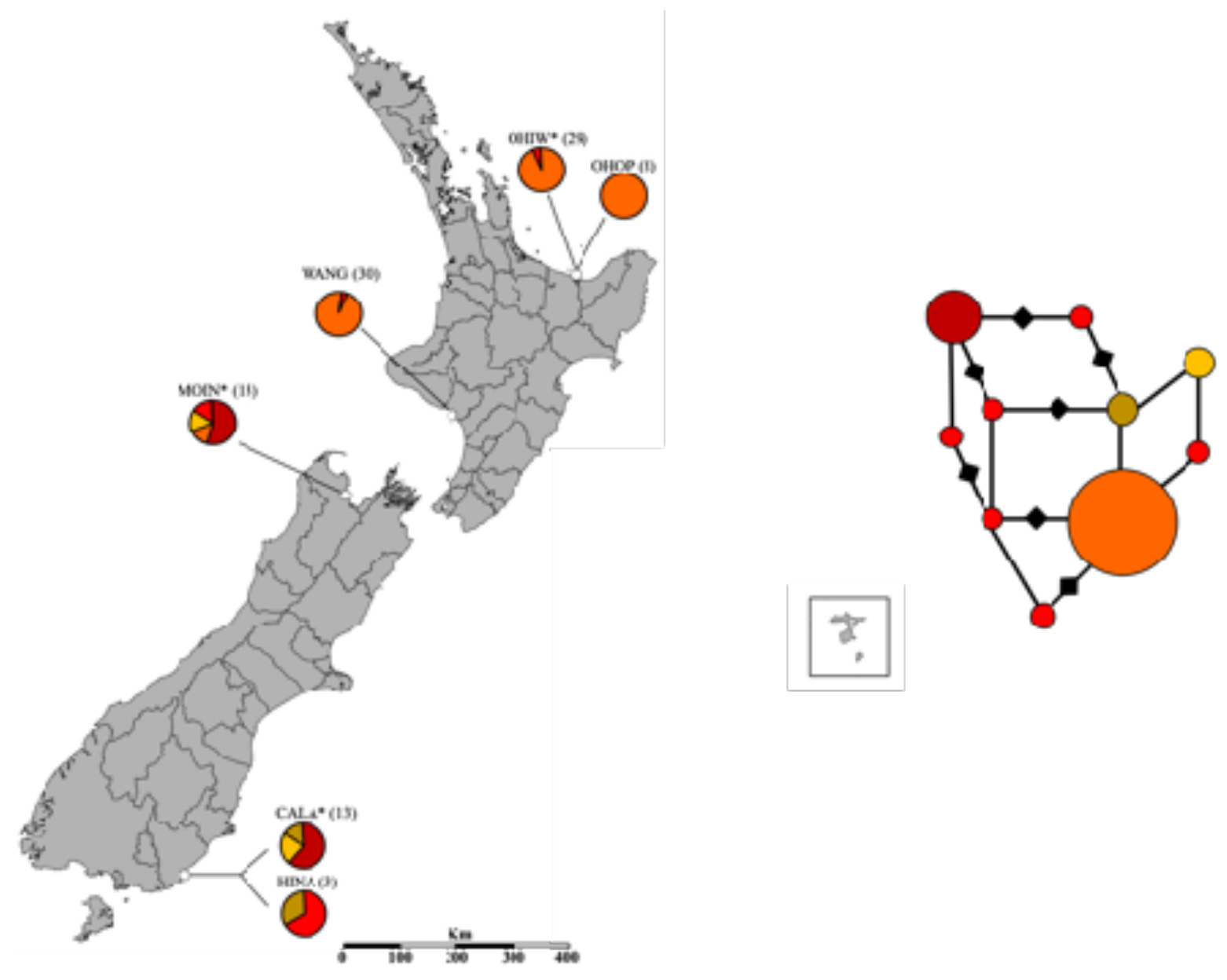

Figure 2: ITS2 ribotype distribution and ITS2 network including 96 sequences of Agarophyton transtasmanicum. Length of ITS2 sequences vary between 494 base pairs (bp) and 497 bp. Pie charts represent ribotype frequency in each sampling site, sequence number in each site is noted between parenthesis, colors correspond to the ones presented in the ITS2 network. In the network, circle sizes are proportional to the ribotype frequency and connection lengths correspond to mutation steps. For ribotypes separated by more than one mutational step, black bars represent the number of steps. Black diamond: indel, for each indel the bp is noted above. Rare and private ribotypes are represented by the same color 
| for clarity. Ribotype number as in Table S2 and S3. *: population of floating thalli; I population abbreviations as in Table 1. 

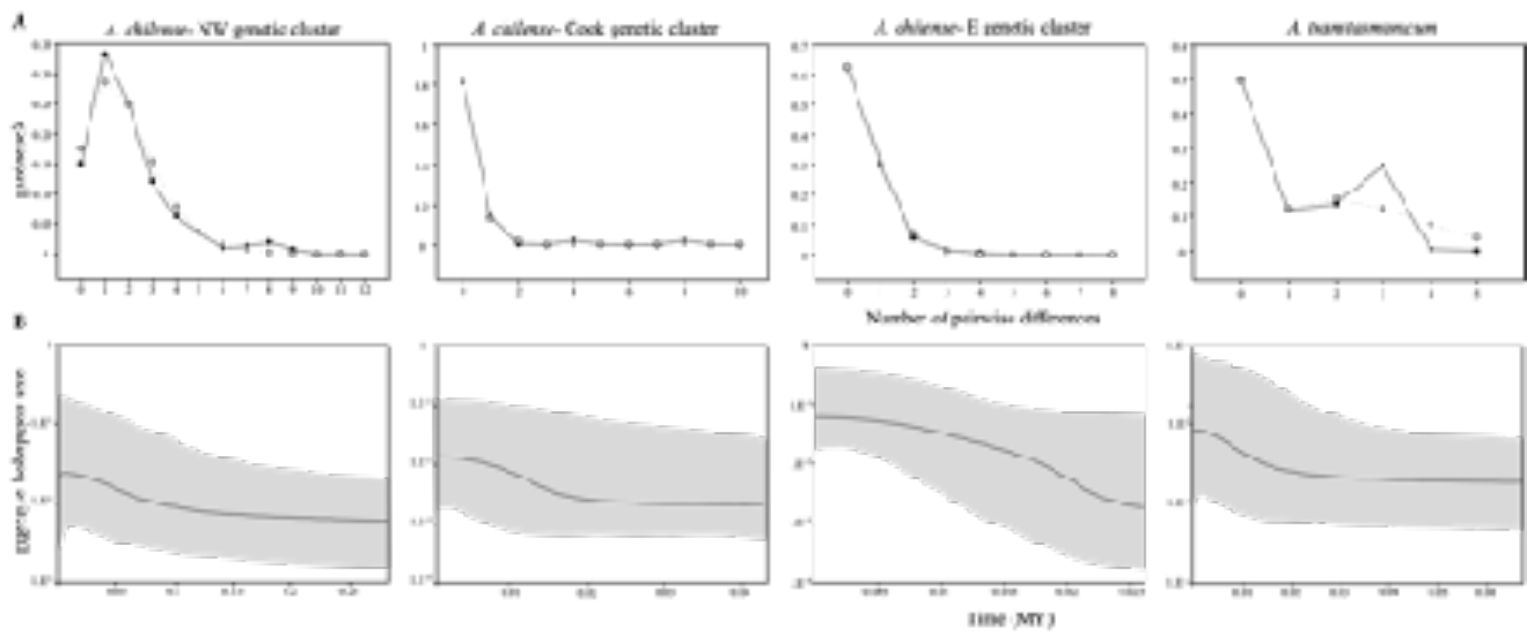

Figure 3: Historical demography of Agarophyton chilense and A. transtasmanicum for

ITS2 sequences. A) Observed mismatch distribution, represented by black circles, and expected mismatch distribution under a spatial expansion model represented by white circles. B) Changes in effective population size estimated by Bayesian Skyline plots. Solid lines are the median posterior effective population size through time; gray area indicates the 95\% confidence interval for each estimate. Each genetic cluster of Agarophyton chilense, defined according to the SAMOVA results, was treated independently.

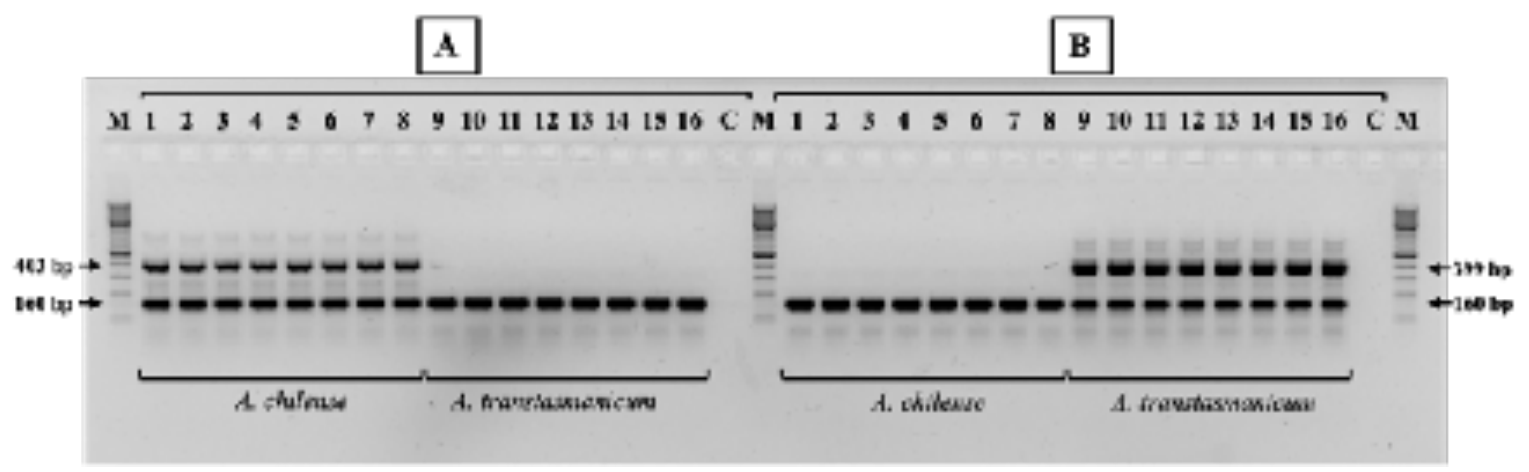


Figure 4: Agarose gel showing results of the two multiplex polymerase chain reaction (PCR) for the diagnostic tool developed in this study, allowing the identification of the two cryptic Agarophyton species in New Zealand. A) PCR reactions using the Agarophyton_COI_F / Agarophyton_COI_R / Agarophyton_chilense_COI_F primer combination; B) PCR reactions using the Agarophyton_COI_F / Agarophyton_COI_R / Agarophyton_trantasmanicum_COI_F primer combination. Samples of A. chilense correspond to lanes 1-8 (1: AHUR, 2: CHAT, 3: OKAR, 4: OTAG, 5: WAIN, 6: MOUT, 7: SHEL, 8: RAGL). Samples of A. transtasmanicum correspond to lanes 9-16 (9 and 10: MOIN, 11 and 12: CALA, 13 and 14: OHIW, 15: OHOP, 16: WANG). Population abbreviations are as in Table 1. C: negative control. M: 100bp molecular weight marker. 
Table S1: Geographical distribution of ITS2 ribotypes in Agarophyton chilense. Number of individuals is given for each ribotype in each sampling site (Code, abbreviation as in Table $1)$.

\begin{tabular}{|c|c|c|c|c|c|c|c|c|c|c|c|c|c|c|c|c|c|c|c|c|c|c|c|c|c|}
\hline $\begin{array}{l}\text { Gen } \\
\text { etic } \\
\text { clust } \\
\text { ers }\end{array}$ & Code & $\begin{array}{c}\mathrm{r} 0 \\
1\end{array}$ & $\begin{array}{c}\mathrm{r} 0 \\
7\end{array}$ & $\begin{array}{r}\mathrm{r} 0 \\
8\end{array}$ & $\begin{array}{c}\mathrm{r} 0 \\
9\end{array}$ & $\begin{array}{c}\text { r1 } \\
0\end{array}$ & $\begin{array}{c}\text { r1 } \\
1\end{array}$ & $\begin{array}{c}\text { r1 } \\
2\end{array}$ & $\begin{array}{c}\mathrm{r} 1 \\
3\end{array}$ & $\begin{array}{r}\mathrm{r} 1 \\
4\end{array}$ & $\begin{array}{c}\mathrm{r} 1 \\
5\end{array}$ & $\begin{array}{c}\text { r1 } \\
6\end{array}$ & $\begin{array}{r}\mathrm{r} 1 \\
7\end{array}$ & $\begin{array}{c}\mathrm{r} 1 \\
8\end{array}$ & $\begin{array}{c}\mathrm{r} 1 \\
9\end{array}$ & $\begin{array}{r}\mathrm{r} 2 \\
0\end{array}$ & $\begin{array}{c}\mathrm{r} 2 \\
1\end{array}$ & $\begin{array}{c}\mathrm{r} 2 \\
2\end{array}$ & $\begin{array}{r}\mathrm{r} 2 \\
3\end{array}$ & $\begin{array}{c}\mathrm{r} 2 \\
4\end{array}$ & $\begin{array}{c}\mathrm{r} 2 \\
5\end{array}$ & $\begin{array}{r}\mathrm{r} 2 \\
6\end{array}$ & $\begin{array}{c}\mathrm{r} 2 \\
7\end{array}$ & $\begin{array}{c}\mathrm{r} 2 \\
8\end{array}$ & $\begin{array}{r}\mathrm{r} 2 \\
9\end{array}$ \\
\hline \multirow[t]{2}{*}{ NW } & $\begin{array}{c}\text { SHE } \\
\text { L }\end{array}$ & & & & & & & & & & & & & & & & & 4 & 1 & 1 & 5 & 1 & 7 & 7 & \\
\hline & $\begin{array}{c}\text { RAG } \\
\text { L }\end{array}$ & & & & & & & & & & & & & & & & & 4 & & & 4 & & 1 & 7 & 2 \\
\hline \multirow[t]{3}{*}{$\begin{array}{c}\mathrm{Coo} \\
\mathrm{k}\end{array}$} & $\begin{array}{c}\text { WAI } \\
\mathrm{N}\end{array}$ & & & & & & & & 20 & & & & & & & & 1 & & & & & & & & \\
\hline & $\begin{array}{c}\text { GOL } \\
\text { D }\end{array}$ & & & & & & & & 7 & 1 & & & & & & & & & & & & & & & \\
\hline & $\begin{array}{l}\text { MO } \\
\text { UT }\end{array}$ & & & & & & & & 46 & & 1 & 1 & & & & & & & & & & & & & \\
\hline \multirow{14}{*}{ E } & $\begin{array}{c}\text { PAR } \\
\text { E }\end{array}$ & 9 & & & & & & & & & & & 25 & & & & & & & & & & & & \\
\hline & $\begin{array}{c}\text { PAU } \\
\text { A }\end{array}$ & 6 & & & & & & & & & & & 19 & & & & & & & & & & & & \\
\hline & $\begin{array}{c}\mathrm{SCO} \\
\mathrm{R}\end{array}$ & 10 & & & & & & & & & & & & 1 & 4 & & & & & & & & & & \\
\hline & $\begin{array}{c}\mathrm{AHU} \\
\mathrm{R}\end{array}$ & 11 & & & & & & & & & & & & & & & & & & & & & & & \\
\hline & $\begin{array}{c}\text { WIT } \\
\text { I }\end{array}$ & 14 & & & & & & & & & & & & & & & & & & & & & & & \\
\hline & $\begin{array}{c}\mathrm{OHO} \\
\mathrm{P}\end{array}$ & 19 & & & & & & & & & & & & & & & & & & & & & & & \\
\hline & $\begin{array}{c}\text { OKA } \\
\text { R }\end{array}$ & 19 & & & & & & & & & & & & & & & & & & & & & & & \\
\hline & $\begin{array}{l}\mathrm{MO} \\
\mathrm{MO}\end{array}$ & 19 & & & & & & & & & & & & & & & & & & & & & & & \\
\hline & $\begin{array}{c}\text { CAS } \\
\mathrm{S}\end{array}$ & 16 & & & & & & & & & & & & & & & & & & & & & & & \\
\hline & $\begin{array}{c}\text { RIV } \\
\text { E }\end{array}$ & 19 & & & & & & & & & & & & & & & & & & & & & & & \\
\hline & $\begin{array}{c}\text { STE } \\
\text { W }\end{array}$ & 34 & & & & & & & & & & & & & & 1 & & & & & & & & & \\
\hline & $\begin{array}{c}\text { CAL } \\
\text { A }\end{array}$ & 11 & & & & & & & & & & & & & & & & & & & & & & & \\
\hline & $\begin{array}{c}\text { HIN } \\
\text { A }\end{array}$ & 23 & 1 & & & & & & & & & & & & & & & & & & & & & & \\
\hline & $\begin{array}{c}\text { OTA } \\
\text { G }\end{array}$ & 19 & & & & & & & & & & & & & & & & & & & & & & & \\
\hline
\end{tabular}




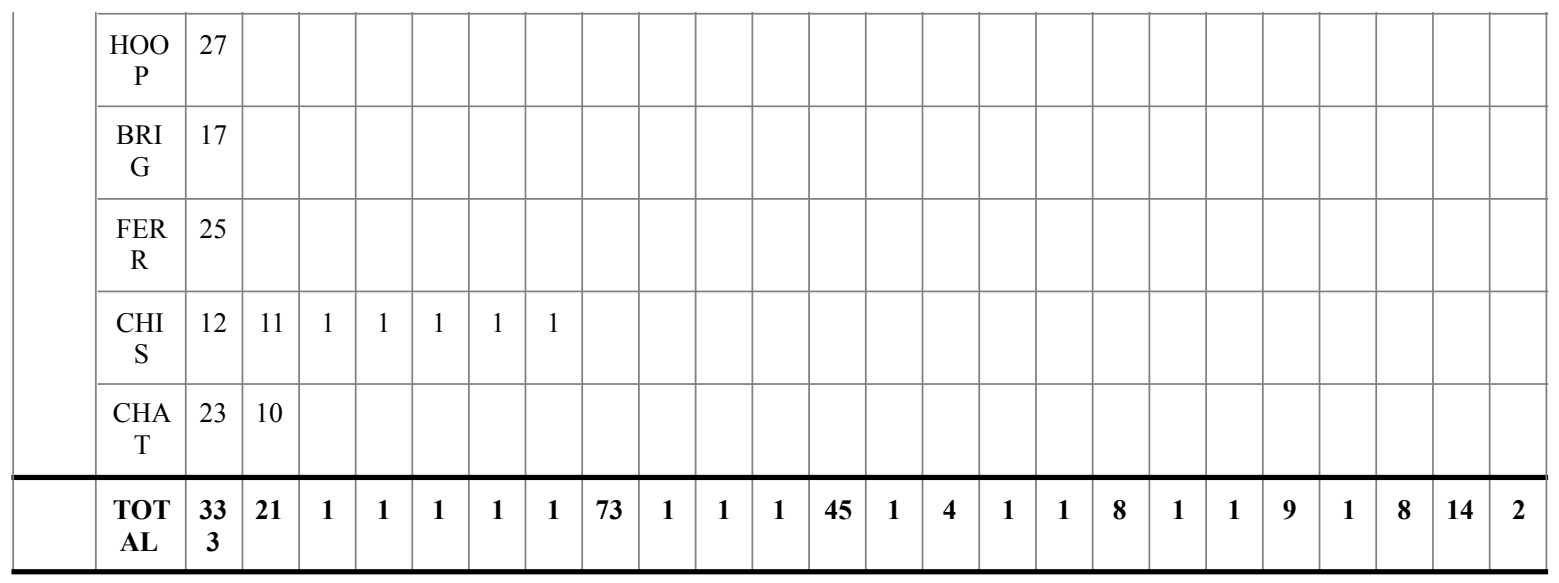

Continued - Table S1

\begin{tabular}{|c|c|c|c|c|c|c|c|c|c|c|c|c|c|c|c|c|c|c|c|c|c|c|c|}
\hline $\begin{array}{l}\text { Genetic } \\
\text { clusters }\end{array}$ & Code & $\begin{array}{c}\mathrm{r} 3 \\
0\end{array}$ & $\begin{array}{c}\mathrm{r} 3 \\
1\end{array}$ & $\begin{array}{c}r 3 \\
2\end{array}$ & $\begin{array}{c}r 3 \\
3\end{array}$ & $\begin{array}{r}r 3 \\
4\end{array}$ & $\begin{array}{r}\mathrm{r} 3 \\
5\end{array}$ & $\begin{array}{c}\text { r3 } \\
6\end{array}$ & $\begin{array}{l}\text { r3 } \\
7\end{array}$ & $\begin{array}{c}\mathrm{r} 3 \\
8\end{array}$ & $\begin{array}{c}\text { r3 } \\
9\end{array}$ & $\begin{array}{c}\mathrm{r} 4 \\
0\end{array}$ & $\begin{array}{c}\mathrm{r} 4 \\
1\end{array}$ & $\begin{array}{c}\mathrm{r} 4 \\
2\end{array}$ & $\begin{array}{c}\mathrm{r} 4 \\
3\end{array}$ & $\begin{array}{c}\mathrm{r} 4 \\
4\end{array}$ & $\begin{array}{c}\mathrm{r} 4 \\
5\end{array}$ & $\begin{array}{c}\mathrm{r} 4 \\
6\end{array}$ & $\begin{array}{r}\mathrm{r} 4 \\
7\end{array}$ & $\begin{array}{c}\mathrm{r} 4 \\
8\end{array}$ & $\begin{array}{c}\mathrm{r} 4 \\
9\end{array}$ & $\begin{array}{c}\text { r5 } \\
0\end{array}$ & $\begin{array}{c}\text { TOT } \\
\text { AL }\end{array}$ \\
\hline \multirow[t]{2}{*}{ NW } & $\begin{array}{c}\text { SHE } \\
\text { L }\end{array}$ & & & & & & & & & & & & & & & & & & & & & & 26 \\
\hline & $\begin{array}{c}\text { RAG } \\
\text { L }\end{array}$ & 1 & 1 & 1 & 1 & 1 & 1 & & & & & & & & & & & & & & & & 24 \\
\hline \multirow[t]{3}{*}{ Cook } & $\begin{array}{l}\text { WAI } \\
\mathrm{N}\end{array}$ & & & & & & & & & & & & & 1 & 1 & & & & & & & & 23 \\
\hline & $\begin{array}{c}\text { GOL } \\
\text { D }\end{array}$ & & & & & & & & & & & & & & & & & & & & & & 8 \\
\hline & $\begin{array}{l}\text { MO } \\
\text { UT }\end{array}$ & & & & & & & & & & & & & & & 1 & & & & & & & 49 \\
\hline & $\begin{array}{c}\text { PAR } \\
\text { E }\end{array}$ & & & & & & & & & & & & & & & & & & & & & & 34 \\
\hline & $\begin{array}{c}\text { PAU } \\
\text { A }\end{array}$ & & & & & & & 1 & 1 & 1 & & & & & & & & & & & & & 28 \\
\hline & $\begin{array}{c}\mathrm{SCO} \\
\mathrm{R}\end{array}$ & & & & & & & & & & & & & & & & & & & & & & 15 \\
\hline & $\begin{array}{c}\mathrm{AHU} \\
\mathrm{R}\end{array}$ & & & & & & & & & & 5 & 1 & 1 & & & & & & & & & & 18 \\
\hline & WITI & & & & & & & & & & & & & & & & & & & & & & 14 \\
\hline
\end{tabular}




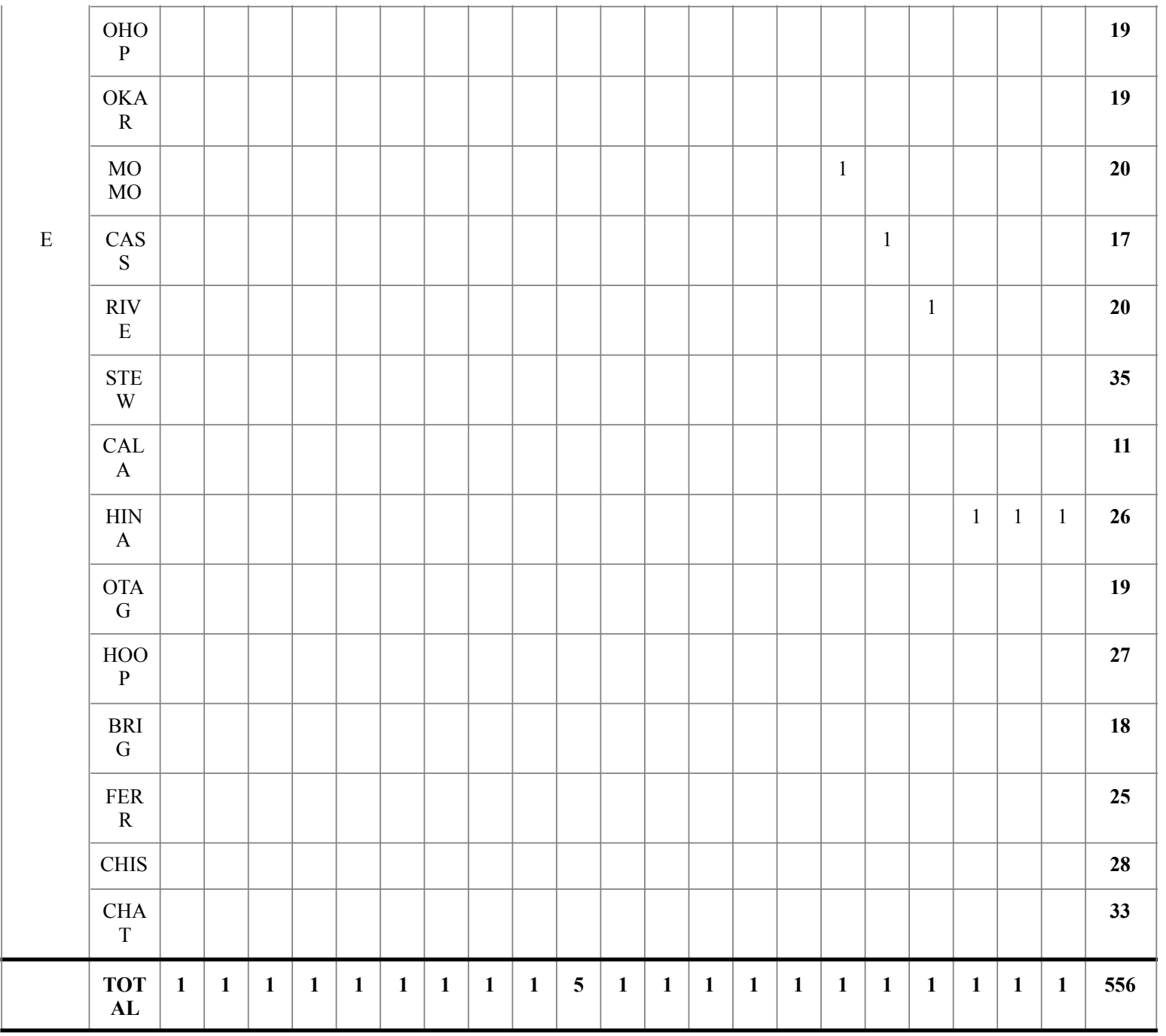

Note that ribotypes $02,03,04,05$, and 06 are not listed in Table S1. These ribotypes where only encountered in Agarophyton chilense in Chile and have been reported in Guillemin et al. (2014). 
Table S2: Ribotypes and GenBank access numbers of Agarophyton chilense and A. transtasmanicum.

\begin{tabular}{|c|c|c|c|c|}
\hline Species & Ribotype & $\begin{array}{l}\text { Genbank } \\
\text { access } N^{\circ}\end{array}$ & $\begin{array}{c}\text { Sequence } \\
\text { deposited in } \\
\text { Genbank }\end{array}$ & Source \\
\hline \multirow[t]{13}{*}{ A. chilense } & r01 & HQ998639 & CH-LEN-LEF102 & $\begin{array}{l}\text { Guillemin et al. } \\
\qquad 2014\end{array}$ \\
\hline & r07 & HQ998748 & NZ-CHT-CHAT15 & $\begin{array}{l}\text { Guillemin et al. } \\
\qquad 2014\end{array}$ \\
\hline & $\mathrm{r} 08$ & HQ998749 & NZ-CHT-CHAT2 & $\begin{array}{l}\text { Guillemin et al. } \\
\qquad 2014\end{array}$ \\
\hline & r09 & HQ998750 & NZ-CHT-CHAT20 & $\begin{array}{l}\text { Guillemin et al. } \\
\qquad 2014\end{array}$ \\
\hline & $\mathrm{r} 10$ & HQ998753 & NZ-CHT-CHAT14 & $\begin{array}{l}\text { Guillemin et al. } \\
\qquad 2014\end{array}$ \\
\hline & r11 & HQ998754 & NZ-CHT-CHAT3 & $\begin{array}{l}\text { Guillemin et al. } \\
2014\end{array}$ \\
\hline & $\mathrm{r} 12$ & HQ998755 & NZ-CHT-CHAT16 & $\begin{array}{l}\text { Guillemin et al. } \\
\qquad 2014\end{array}$ \\
\hline & r13 & HQ998759 & NZ-PGB-GB4 & $\begin{array}{l}\text { Guillemin et al. } \\
\qquad 2014\end{array}$ \\
\hline & r14 & HQ998764 & NZ-PGB-GB3 & $\begin{array}{l}\text { Guillemin et al. } \\
\qquad 2014\end{array}$ \\
\hline & $\mathrm{r} 15$ & HQ998772 & $\begin{array}{l}\text { NZ-MOU- } \\
\text { MOUT16 }\end{array}$ & $\begin{array}{l}\text { Guillemin et al. } \\
\qquad 2014\end{array}$ \\
\hline & r16 & HQ998777 & $\begin{array}{l}\text { NZ-MOU- } \\
\text { MOUT3 }\end{array}$ & $\begin{array}{l}\text { Guillemin et al. } \\
\qquad 2014\end{array}$ \\
\hline & r17 & HQ998779 & NZ-PIW-PIW12 & $\begin{array}{l}\text { Guillemin et al. } \\
\qquad 2014\end{array}$ \\
\hline & r18 & HQ998792 & NZ-SCB-SB10 & $\begin{array}{l}\text { Guillemin et al. } \\
\qquad 2014\end{array}$ \\
\hline
\end{tabular}




\begin{tabular}{|c|c|c|c|}
\hline r19 & HQ998796 & NZ-SCB-SB14 & $\begin{array}{l}\text { Guillemin et al. } \\
\qquad 2014\end{array}$ \\
\hline r20 & HQ998816 & NZ-STI-STIS2 & $\begin{array}{l}\text { Guillemin et al. } \\
\qquad 2014\end{array}$ \\
\hline $\mathrm{r} 21$ & HQ998824 & NZ-WIN-WIN10 & $\begin{array}{l}\text { Guillemin et al. } \\
\qquad 2014\end{array}$ \\
\hline r22 & MN145944 & SHEL_01 & This study \\
\hline r23 & MN145945 & SHEL_05 & This study \\
\hline r24 & MN145946 & SHEL_06 & This study \\
\hline r25 & MN145947 & SHEL_07 & This study \\
\hline r26 & MN145948 & SHEL_16 & This study \\
\hline r27 & MN145949 & SHEL_20 & This study \\
\hline r28 & MN145950 & SHEL_22 & This study \\
\hline r29 & MN145951 & RAGL_01 & This study \\
\hline r30 & MN145952 & RAGL_04 & This study \\
\hline r31 & MN145953 & RAGL_03 & This study \\
\hline r32 & MN145954 & RAGL_10 & This study \\
\hline r33 & MN145955 & RAGL_15 & This study \\
\hline r34 & MN145956 & RAGL_13 & This study \\
\hline r35 & MN145957 & RAGL_33 & This study \\
\hline r36 & MN145958 & PAUA_02 & This study \\
\hline r37 & MN145959 & PAUA_19 & This study \\
\hline r38 & MN145960 & PAUA_26 & This study \\
\hline r39 & MN145961 & AHUR_02 & This study \\
\hline $\mathrm{r} 40$ & MN145962 & AHUR_04 & This study \\
\hline r41 & MN145963 & AHUR_08 & This study \\
\hline $\mathrm{r} 42$ & MN145964 & WAIN_03 & This study \\
\hline $\mathrm{r} 43$ & MN145965 & WAIN_08 & This study \\
\hline
\end{tabular}




\begin{tabular}{|c|c|c|c|c|}
\hline & \multirow{2}{*}{$\begin{array}{l}r 44 \\
r 45\end{array}$} & MN145966 & MOUT_30 & This study \\
\hline & & MN145967 & MOMO_18 & This study \\
\hline & $\mathrm{r} 46$ & MN145968 & CASS_40 & This study \\
\hline & $\mathrm{r} 47$ & MN145969 & RIVE_14 & This study \\
\hline & $\mathrm{r} 48$ & MN145970 & HINA_25 & This study \\
\hline & r49 & MN145971 & HINA_31 & This study \\
\hline & r50 & MN145972 & HINA_39 & This study \\
\hline \multirow{10}{*}{$\begin{array}{c}\text { A. } \\
\text { transtasmanicu } \\
m\end{array}$} & $\mathrm{r} 1$ & MN145973 & OHIW_01 & This study \\
\hline & $\mathrm{r} 2$ & MN145974 & OHIW_15 & This study \\
\hline & r3 & MN145975 & WANG_35 & This study \\
\hline & r4 & MN145975 & MOIN_04 & This study \\
\hline & r5 & MN145977 & MOIN_07 & This study \\
\hline & r6 & MN145978 & MOIN_31 & This study \\
\hline & r7 & MN145979 & MOIN_39 & This study \\
\hline & r8 & MN145980 & CALA_01 & This study \\
\hline & r9 & MN145981 & HINA_11 & This study \\
\hline & $\mathrm{r} 10$ & MN145982 & HINA_18 & This study \\
\hline
\end{tabular}

Note that ribotypes $02,03,04,05$, and 06 are not listed in Table S1. These ribotypes where only encountered in Agarophyton chilense in Chile and have been reported in Guillemin et al. (2014). 
Table S3: Geographical distribution of ITS2 ribotypes in Agarophyton transtasmanicum.

Number of individuals is given for each ribotype in each sampling site (Code, abbreviation as in Table 1).

\begin{tabular}{|c|c|c|c|c|c|c|c|c|c|c|c|}
\hline Code & r01 & r02 & r03 & r04 & r05 & r06 & r07 & r08 & r09 & r10 & TOTAL \\
\hline OHIW & 27 & 2 & & & & & & & & & $\mathbf{2 9}$ \\
\hline WANG & 29 & & 1 & & & & & & & & $\mathbf{3 0}$ \\
\hline MOIN & 2 & & & 1 & 7 & 2 & 1 & & & & $\mathbf{1 3}$ \\
\hline CALA & & & & & 8 & 3 & & 2 & & & $\mathbf{1 3}$ \\
\hline OHOP & 8 & & & & & & & & & & $\mathbf{8}$ \\
\hline HINA & & & & & & & & 1 & 1 & 1 & $\mathbf{3}$ \\
\hline TOTAL & $\mathbf{6 6}$ & $\mathbf{2}$ & $\mathbf{1}$ & $\mathbf{1}$ & $\mathbf{1 5}$ & $\mathbf{5}$ & $\mathbf{1}$ & $\mathbf{3}$ & $\mathbf{1}$ & $\mathbf{1}$ & $\mathbf{9 6}$ \\
\hline
\end{tabular}


Table S4: Spatial analysis of molecular variance (SAMOVA) of Agarophyton chilense for the ITS2 marker. K, number of groups. FSC, proportion of total genetic variance due to differences between populations within each group. $F_{C T}$, proportion of total genetic variance due to the differences between groups. Population abbreviations as in Table 1. * $\mathrm{p}<0.001$. K for which Fct was maximized is indicated in bold.

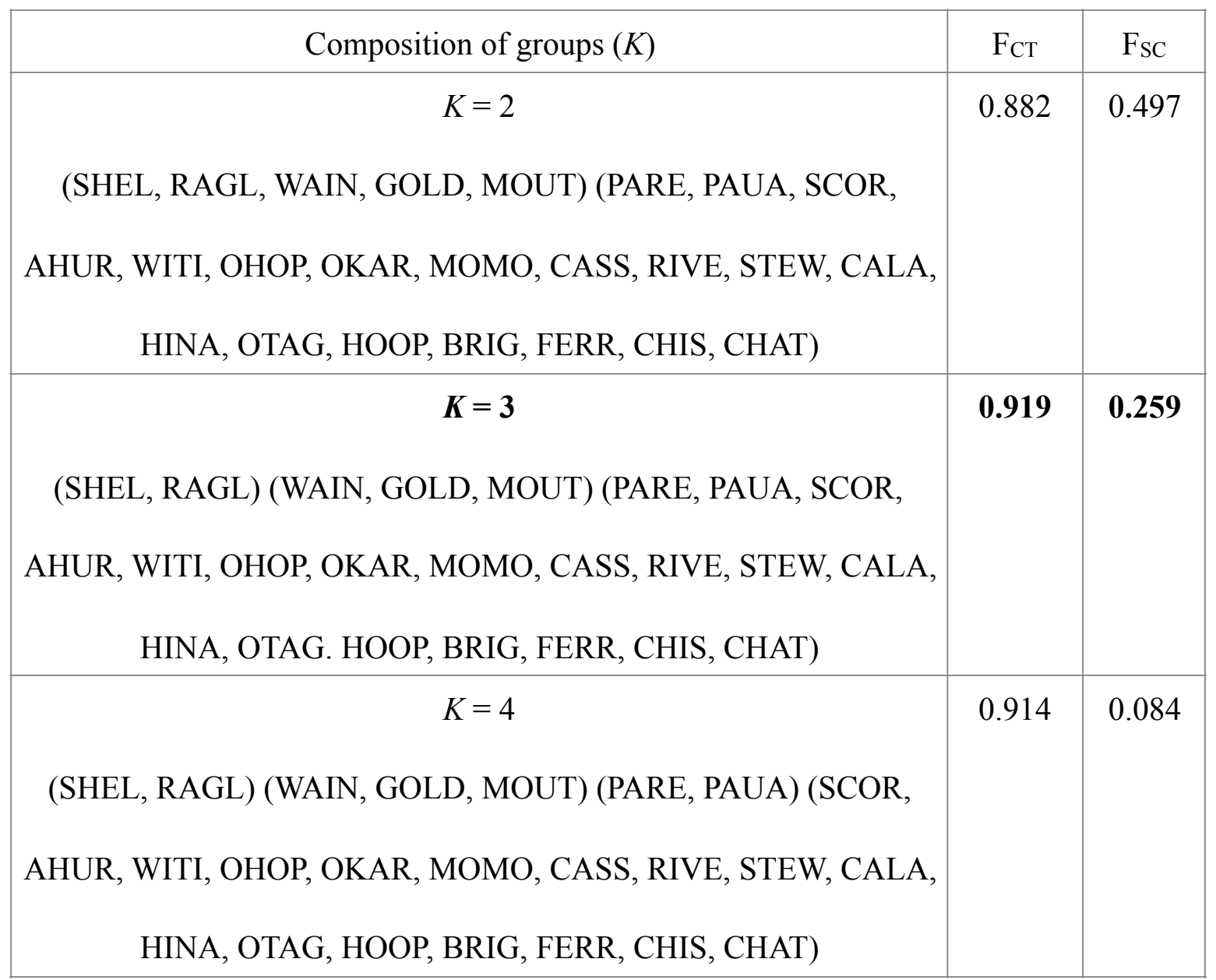

